\title{
Environmental influence of gaseous emissions from self- heating coal waste dumps in Silesia, Poland
}

\author{
Monika Fabiańska • Justyna Ciesielczuk • Ádám Nádudvari • Magdalena Misz-Kennan • \\ Adam Kowalski • Lukasz Kruszewski
}

Received: 4 July 2017 / Accepted: 12 July 2018/Published online: 24 July 2018

(C) The Author(s) 2018

\begin{abstract}
Gaseous emissions from seven self-heating coal waste dumps in two large coal mining basins, Upper and Lower Silesia (Poland), were investigated by gas chromatography (GC-FID/TCD), and the results were correlated with on-site thermal activity, stage of self-heating as assessed by thermal mapping, efflorescences, and surface and subsurface temperatures. Though typical gases at sites without thermal activity are dominated by atmospheric nitrogen and oxygen, methane and carbon dioxide are present in concentrations that many times exceed atmospheric
\end{abstract}

Electronic supplementary material The online version of this article (https://doi.org/10.1007/s10653-018-0153-5) contains supplementary material, which is available to authorized users.

M. Fabiańska $(凹) \cdot$ J. Ciesielczuk · M. Misz-Kennan Faculty of Earth Sciences, University of Silesia, 60 Będzińska Street, 41-200 Sosnowiec, Poland e-mail: monika.fabianska@us.edu.pl

Á. Nádudvari

Institute for Ecology of Industrial Areas, 6 Kossuth Street, 40-844 Katowice, Poland

A. Kowalski

Faculty of Geology, Geophysics and Environmental Protection, AGH University of Science and Technology, 30 Mickiewicza Avenue, 30-059 Cracow, Poland

Ł. Kruszewski

Institute of Geological Sciences, Polish Academy of

Sciences (ING PAN), 51/55 Twarda Street,

00-818 Warsaw, Poland values. On average, their concentrations are 42.7-7160 ppm, respectively. These are levels considered harmful to health and show that coal waste fire can be dangerous for some years after extinction. At thermally active sites, concentrations of $\mathrm{CH}_{4}$ and $\mathrm{CO}_{2}$ are much higher and reach 5640-51,976 ppm (aver.), respectively. A good substrate-product correlation between $\mathrm{CO}_{2}$ and $\mathrm{CH}_{4}$ concentrations indicates rapid in-dump $\mathrm{CH}_{4}$ oxidation with only insignificant amounts of $\mathrm{CO}$ formed. Other gas components include hydrogen, and $\mathrm{C}_{3}-\mathrm{C}_{6}$ saturated and unsaturated hydrocarbons. Decreasing oxygen content in the gases is temperature-dependent, and $\mathrm{O}_{2}$ removal rapidly increased at $>70{ }^{\circ} \mathrm{C}$. Emission differences between both basins are minor and most probably reflect the higher maturity of coal waste organic matter in the Lower Silesia dumps causing its higher resistance to temperature, or/and a higher degree of overburning there.

Keywords Coal wastes · Self-heating · Gas emission · Volatile organic compounds · Greenhouse gases

\section{Introduction}

Coal waste dumps, a common landscape feature in coal mining regions, are a potential source of hazardous substances emitted to the atmosphere and 
leached to surface and ground waters (e.g., Grossman et al. 1994; Stracher and Taylor 2004; Finkelman 2004; Pone et al. 2007; Querol et al. 2008; Carras et al. 2009; Hower et al. 2009; O'Keefe et al. 2010; Skręt et al. 2010). Negative influences on the environment are increased in the case of dumps where self-heating, or even open fire, occurs; these processes release a wide variety of gases and water-soluble inorganic and organic compounds.

Recent research has focused on the reasons for selfheating, its prevention and fire extinction (e.g., Krishnaswamy et al. 1996a, b; Kaymakçi and Didari 2002; Singh et al. 2007; Querol et al. 2011). However, a developing awareness of the environmental impact has increased attention on self-heating products and their polluting potential. The gaseous products are of particular interest due to their toxicity, carcinogenicity, and greenhouse significance, even though it is very difficult to reliably assess total quantities expelled in any given instance (e.g., Yan et al. 2003; Stracher and Taylor 2004; Finkelman 2004; Younger 2004; Kim 2007). As gases and volatile organic compounds (VOCs) are the first substances released during the initial low-temperature stage, they can be used to monitor the thermal state of coal waste dumps (Tabor 2002; Xie et al. 2011). As these dumps are commonly located in highly populated industrial regions, they should be deemed major environmental and health hazards. Though persistent odors and dust are an obvious problem for nearby residents, the most harmful emissions (e.g., $\mathrm{CO}, \mathrm{CO}_{2}$, and monoaromatic hydrocarbons) are odorless. The gases also contain $\mathrm{NO}_{\mathrm{x}}, \mathrm{NH}_{3}, \mathrm{SO}_{\mathrm{x}}$, and $\mathrm{H}_{2} \mathrm{~S}$ from the thermal decomposition of sulfide minerals, $\mathrm{HCl}$, light aliphatic compounds up to $\mathrm{C}_{10}$, aromatic compounds such as benzene and its alkyl derivatives, styrene, alcohols, PAHs, and heavy metals, e.g., $\mathrm{Hg}, \mathrm{As}, \mathrm{Pb}$, and $\mathrm{Se}$ (Stracher and Taylor 2004; Pone et al. 2007; O'Keefe et al. 2010; Querol et al. 2011). Halogenated organic compounds, e.g., $\mathrm{CH}_{3} \mathrm{Cl}$, may form during the thermal decay of clay minerals and subsequent hydrohalogen reactions with organic matter (Davidi et al. 1995; Fabiańska et al. 2013). Sulfur, oxygen, and nitrogen heterocyclic compounds such as furane, thiophene, and pyridine derivatives have also been noted (Ribeiro et al. 2010).

The major compound emitted during self-heating is $\mathrm{CO}_{2}$, accompanied by $\mathrm{CO}$ and light organic compounds. These derive partially from gaseous compounds trapped in organic matter pores and partly from pyrolysis, depending on the temperature range, coal rank, and oxygen availability (Davidi et al. 1995; Younger 2004; Querol et al. 2008). It is extremely difficult to assess the scale of emission of the two main greenhouse gases, $\mathrm{CO}_{2}$ and $\mathrm{CH}_{4}$, in the field due to spatial and temporal emission variability, mixing of gas with air, the large volume of coal wastes, and the influence of weather (Litschke 2005). Research on emission fluxes from Australian coal waste dumps has shown $\mathrm{CO}_{2}$ emission from 12 to $8200 \mathrm{~kg} \mathrm{CO} / \mathrm{m}^{2}$ per year (Carras et al. 2009). Liu et al. (1998) estimated that the combustion of one tonne of coal waste can generate $99.7 \mathrm{~kg} \mathrm{CO}, 0.61 \mathrm{~kg} \mathrm{H}_{2} \mathrm{~S}, 0.03 \mathrm{~kg} \mathrm{NO}$, $0.84 \mathrm{~kg} \mathrm{SO}_{2}$, and $0.45 \mathrm{~kg}$ smoke.

The aims of our study were (a) to examine the variability in occurrence and distribution of the main gas components emitted from self-heating dumps in Upper and Lower Silesia, (b) to establish whether differences in gas distributions are related to thermal stage, (c) to compare the activity and dynamics of selfheating in the two basins, and (d) to assess levels of hazardous gas emissions in both. Preliminary research on gas compositions performed in Upper Silesia (Fabiańska et al. 2013) aided selection of appropriate components.

\section{Materials and methods}

Coal waste dumps

\section{Wetnowiec dump (Upper Silesia)}

The Wełnowiec dump in Katowice operated as a municipal waste dump from 1991 to 1996 (Figs. 1 and S1a). The dump area is 16 ha and its capacity is $1.6 \mathrm{mln}$ t. About $22.5 \%$ of the deposited waste is gangue rock from coal mining (sandstones, carbonates, siltstones, and clays), $21.5 \%$ is municipal waste, and $40 \%$ is rubble. A reclamation project was designed to involve a multilayered barrier system comprising layers of soil, coal waste with $<5 \%$ organic matter, gravel, sand, and clay liners. In fact, a much thicker layer of coal waste with much higher carbon contents was deposited in a random fashion with no evidence of any barriers. As a result, self-heating started. Temperatures reached ca $700{ }^{\circ} \mathrm{C}$ (Ciesielczuk et al. 2013, 2015). In recent times, heating essentially 


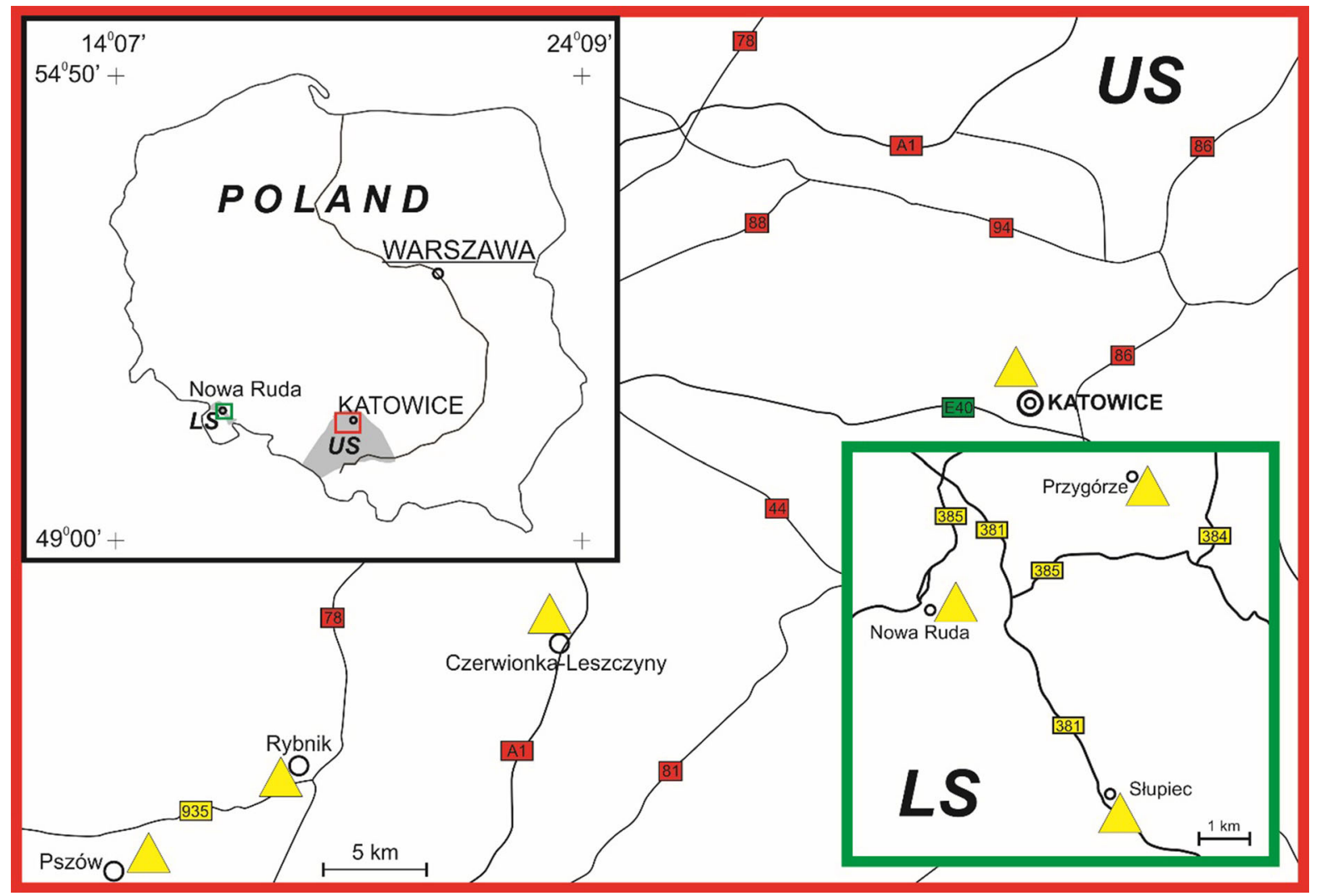

Fig. 1 Location of coal waste dumps from which gas was collected; LS (Lower Silesia) and US (Upper Silesia)

ceased after the application of various fire-extinguishing methods, culminating with the deposition of waste from a sewage cleaning plant.

\section{Rymer cones (Upper Silesia)}

The Rymer Cones dump (Fig. 1) was linked to coal exploitation in the Rymer Coal Mine from 1858 to 2011 (Frużyński 2012). Today, the dump covers the area of $0.13 \mathrm{~km}^{2}$, its height is $>300 \mathrm{~m}$ a.s.l., and its capacity is $2.4 \times 10^{6} \mathrm{~m}^{3}$ (Barosz 2003). Coal waste was loosely deposited in three cones loosely without compaction and without ground sealing. Over time, self-heating has altered most of the waste. To halt the heating, the dump was redeveloped in 1994-1999 and encased with waste from current mining (Tabor 2002; Barosz 2003). In the process, two cones were dismantled and combined, and a plateau formed on top on which fly ash pulp was deposited. The remaining cone was covered with concrete panels and fly ash to block air access and, thereby, to stop the self-heating. These efforts failed, and self-heating restarted and intensified. Currently, activity appears to be slowly diminishing with heating confined mostly to the eastern slope.

\section{Anna dump (Upper Silesia)}

The dump stores waste from the Ruch Anna Coal Mine opened in 1954 in Pszów (Fig. 1). A single cone covers an area of $0.43 \mathrm{~km}^{2}$, the oldest part $\left(\sim 0.20 \mathrm{~km}^{2}\right)$ of which and is $\sim 50 \mathrm{~m}$ high. Planned capacity was $>3 \times 10^{6} \mathrm{~m}^{3}$ (Barosz 2003). Exploitation for road building enabled oxygen access, and intensified self-heating hindered further exploitation. Toxic fumes and odors are now a problem in Pszów (Misz-Kennan et al. 2013). In 2015, the cone was flattened. Any current heating is reflected in puddles of tar, cracks, gas vents, and salamoniac crusts. 


\section{Czerwionka-Leszczyny dump (Upper Silesia)}

The mostly forested dump located in CzerwionkaLeszczyny (Fig. 1) consists of three cones, the highest of which is $\sim 100 \mathrm{~m}$ high. On its top, intense surface pseudo-fumarolic activity is associated with surface gas vents surrounded by sulfate crusts (Parafiniuk and Kruszewski 2010). Some tar puddles reflect heating under pyrolytic conditions that caused thermal cracking of the coal waste organic matter macromolecule. The tar migrated to accumulate on relatively cold coal waste surfaces (Nádudvari and Fabiańska 2016). The thermal activity, extant for more than 30-40 years, is waning, and burnt-out material is evident in parts of the dump (Nádudvari 2014).

\section{Nowa Ruda, Stupiec and Przygórze dumps (Lower Silesia)}

Hard coal exploitation began in Lower Silesia in the 1400s, especially around Wałbrzych and Nowa Ruda (Fig. 1). Several mines operated there in the 1900s. Mining ceased in 2000 when the mines became unprofitable (Frużyński 2012). A few hundred years of mining left coal waste dumps in which self-heating lasted for many tens of years. Despite several attempts to halt them, fires still occur today. The dumps contain waste that is commonly completely altered.

The coal waste dump in Nowa Ruda was heaped up after 1945. Covering an area of ca $0.4 \times 0.5 \mathrm{~km}$, it is $<110 \mathrm{~m}$ high (523 m a.s.1.) and contains $10.2 \mathrm{mln}$ tonnes of waste (Borzęcki and Marek 2013). At present, thermal activity is observed at its top and on the slope nearby. Elsewhere, snow cover remains in winter, unlike as in the past. More thermally active sites occur in the Słupiec dump (Fig. S1b). The dump in Przygórze is now cool though tonnes of overburnt coal waste attest to intense past activity.

Thermal activity of coal waste dumps

How coal waste dumps are affected by fire that depends on a variety of factors, e.g., fire duration, oxygen access, volume of burning waste, the nature of organic material, its content, and petrographic composition. Gas sampling sites were chosen where signs of thermal activity were evident, namely open fire, smoke, odors, charred vents, efflorescences, a lack of vegetation, or the presence of moss or mullein
(Verbascum L.; Figs. S2 and S3). The thermal activity stage was established mainly on field observations and temperature measurements.

Thermal sites classed as 'ongoing' show increased surface and subsurface temperatures, visible smoke, mineral efflorescences, and tar seepage. Thirty-nine gas samples were collected from such at five dumps. 'Initial' thermal activity was recognized only at the Wełnowiec dump (4 samples) in places where fire was beginning to encroach on cool coal waste. Here, temperatures are high, smoke, and odors noticeable, and blooming organic efflorescences prominent. Nine samples are from sites of 'waning' thermal activity marked by lower temperatures and a lack of efflorescences. In addition, five samples are from sites with no current thermal activity; these were never touched by fire or past activity had ceased.

\section{Thermal mapping}

Thermal maps help to reveal the self-heating history of coal waste dumps. They can aid the location of current hot spots, their migration paths, and variations in intensity with time. Regretfully, such archival data are rarely available for dumps. For this study, a series of Landsat 5, 7, and 8 images with snow covering was used. The thermal mapping procedure used is detailed in Nádudvari (2014). Hot spots on the dumps may appear as high-temperature surface anomalies. Extended observation enables recognition of persistent heat sources due to self-heating, and their migration, intensification, and disappearance if they are hot enough to detect with satellite sensors (Tetzlaff 2004; Zhang and Kuenzer 2007; Prakash et al. 2011; Nádudvari 2014).

In general, most coal waste hot spots where intensive fire is present can be detected when $T$ values are $6-14{ }^{\circ} \mathrm{C}$ higher than background surface temperatures (Table S1). Cold and frosty weather can induce a marked decrease in hot-spot surface temperatures (Fig. 2). Where intense fires take place, the lack of snow covering is indicated by NDSI (Normalized Difference Snow Index) values $<0$; abundant snow is indicated by values $>0.5$ (Nádudvari 2014). The resolution of the thermal bands of the applied Landsat series varies from 60 to $120 \mathrm{~m}$ (Landsat TM-120 m, Landsat ETM + - $60 \mathrm{~m}$, Landsat 8-100 m) where pixel size is reduced to $30 \mathrm{~m}$ (https://landsat.usgs.gov/ what-are-band-designations-landsat-satellites). Thus, 


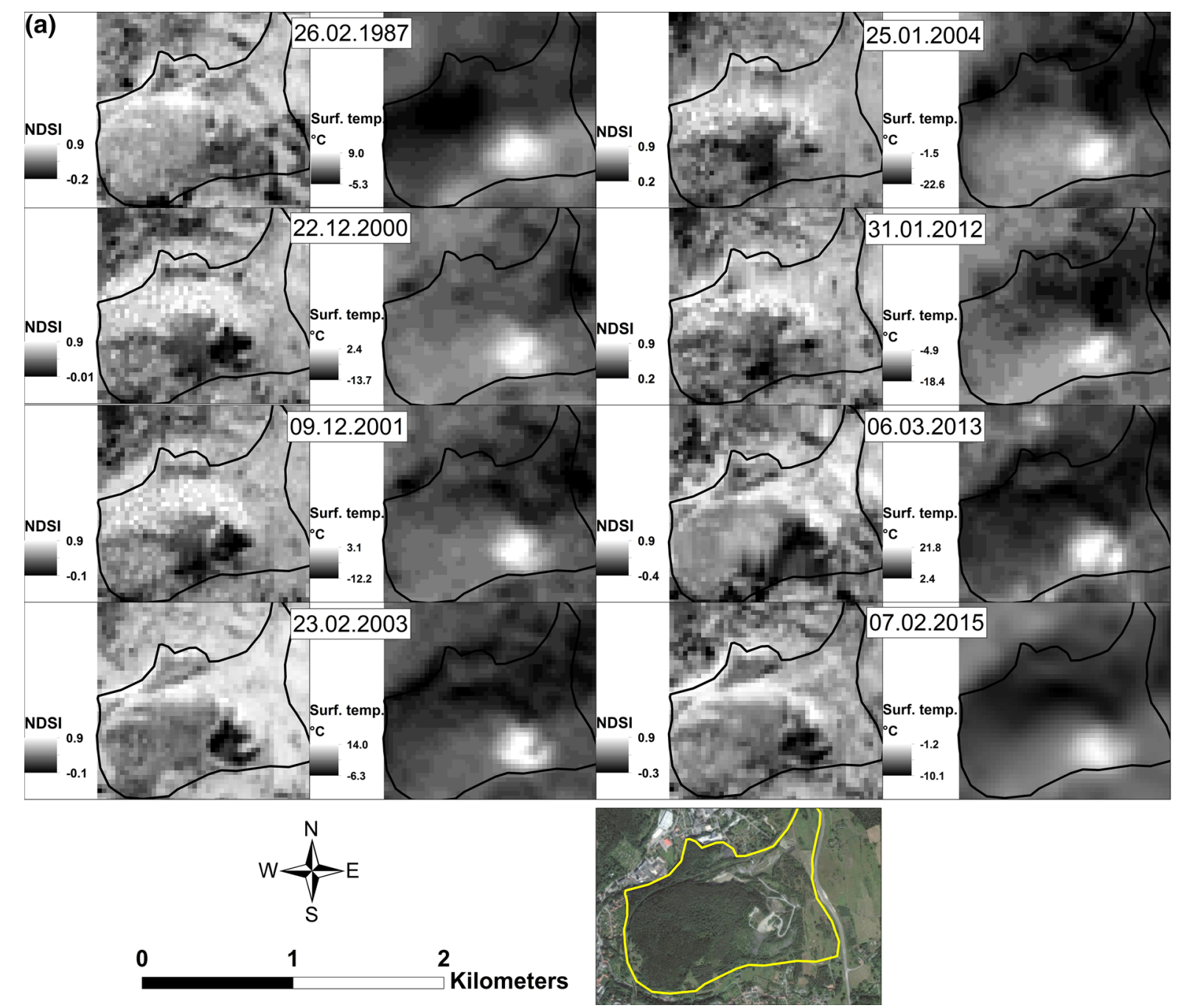

Fig. 2 Development of thermal zones as revealed by thermal mapping. a Nowa Ruda dump (Lower Silesia), b Anna dump (Upper Silesia)

fires falling below these resolutions, or have low surface temperatures, evade detection.

\section{Lower Silesian coal waste dumps}

Eight Landsat images from 1987 to 2015 (NDSI index values and melted snow) clearly show continuous thermal activity during that period in the coal waste dumps in Nowa Ruda (Fig. 2a) and Słupiec. On these dumps, self-heating resulted in elevated temperatures in 1987, 2000, 2001, and 2003 despite mostly sub-zero background temperatures. Since 1987, hot-spot migration is evident in Nowa Ruda, as is the appearance of a new burning site within the constantly active heating zone there. Generally, in all dumps, the intensity of self-heating is waning. The Przygórze dump showed no intense activity during 1987-2015.

\section{Upper Silesian coal waste dumps}

Eight Landsat images from 1993 to 2017 reveal that thermal activity of varying intensity has been constant over that period on the Rymer dump. The self-heating center moved toward the eastern side of the dump and divided into two main hot spots. However, the fires are not characterized by high-temperature anomalies. The relatively low thermal activity here may be due to the covering of concrete panels and a deeper siting of the 


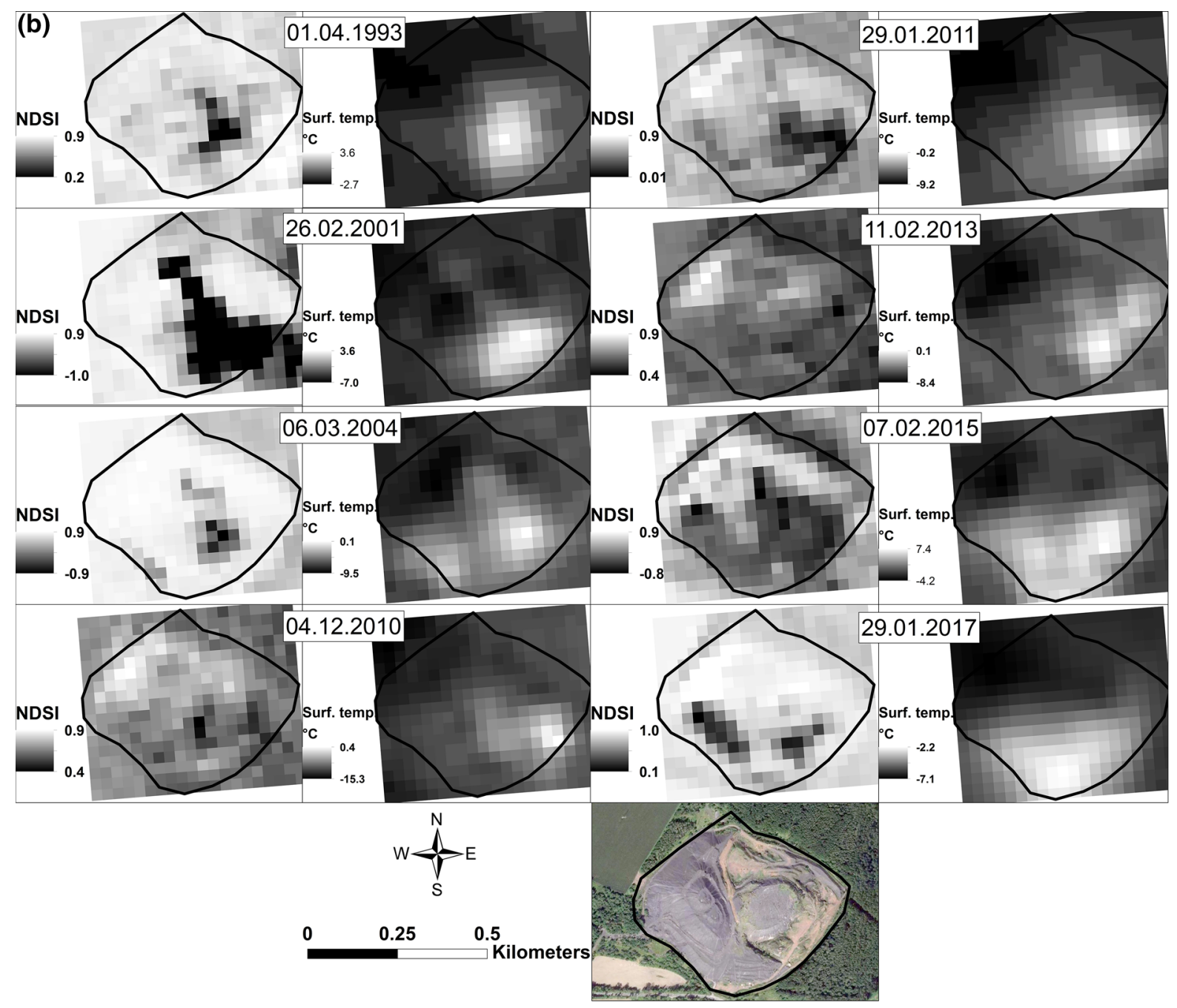

Fig. 2 continued

hot spots. On Wełnowiec dump, intense thermal processes are difficult to distinguish; the hot spots fall below the satellite sensitivity limits. In the Czerwionka-Leszczyny dump, the fire at the top of the highest cone has been waning since the early 1990s (Nádudvari 2014). The Anna dump (Fig. 2b) showed intensive thermal activity in 2001, 2004, and 2010, despite frosty ambient temperatures; the increased activity was a response to exploitation. Today, the heating is less. Though thermal maps for 2017 do not show strong thermal anomalies, possibly reflecting the low resolution of the thermal band of Landsat 8, a lack of snow covering on the southeast side of the dump indicates that burning continues. The lack of snow covering on southwest side is related to deposition of new waste material.

\section{Gas sampling}

Fifty-seven gas samples collected from the seven dumps (Table S2) include 12 from Wełnowiec, 10 from Rymer Cones, 5 from the Anna dump and 5 from Czerwionka-Leszczyny in the Upper Silesian Coal Basin, and 21 from Stupiec, 3 from Nowa Ruda, and 1 from Przygórze in the Lower Silesian Coal Basin (Figs. S2 and S3). Numbers of samples reflected numbers of active sites and their intensity. Only at the Wełnowiec dump was it possible to clearly distinguish 
all three stages of thermal activity. Two sites (W2 and W3) relate to the initial stage, one (W4) to ongoing activity, and two (W5 and W6) to waning fire (Figs. S1a and S2). Sites W1, W7, and W8 that had seen fire in the past were inactive on the day of sampling (13.01.2014). Rymer Cones was sampled on 14.04.2011 (R1a, R2, R4a, R5a, and R6a) and, four years later, on 16.03.2015 (R1b, R3, R4b, R5b, and R6b) at sites of ongoing thermal activity. Samples from the Anna dump and Czerwionka-Leszczyny were collected on 12.11.2016 from sites of thermal activity that had been waning since September 2016 at least. Sampling took place at Słupiec on 13.12.2013 and at Nowa Ruda and Przygórze on 28.5.2014 (Figs. S1b and S3). At Słupiec, ten thermally active sites from the top and slopes of the dump were sampled at varying depths (S1-S10) and a reference sample (S11) was collected at $1 \mathrm{~m}$ depth at a site where thermal activity had never been noted. Though the Nowa Ruda and Przygórze dumps had been very active in the past, at Nowa Ruda, only two sites are still active (N2 and N3) and any in the Przygórze dump has ceased (P1).

Samples $\left(100 \mathrm{~cm}^{3}\right)$ were collected a few centimeters subsurface and deeper $(<1.5 \mathrm{~m})$ using syringe samplers. A $1.5-\mathrm{m}$ steel pipe protected by a clinch was hammered as deeply as possible into vents or heated spots. The clinch was removed, and the gas was collected using a plastic pipe with an attached syringe fixed to the steel pipe. The clinches were abandoned.

Temperature measurements in situ

Temperature was measured using a pyrometer coupled with a K-probe which enabled measurement up to $0.3 \mathrm{~m}$ subsurface (Table S2). Surface temperatures at thermally inactive sites reflected the weather and ambient air temperatures.

Identification of efflorescence compositions

Efflorescences blooming at fissures were identified using SEM-EDS and XRD. The morphologies of samples on carbon tape were examined using a Philips XL 30 ESEM/TMP scanning electron microscope coupled to an energy-dispersive spectrometer (EDS; EDAX type Sapphire) at the Faculty of Earth Sciences, University of Silesia. Analytical conditions were: accelerating voltage $15 \mathrm{kV}$, working distance ca $10 \mathrm{~mm}$, and counting time $40 \mathrm{~s}$. In addition, powdered samples were examined using a Bruker AXS D8 ADVANCE diffractometer in the X-Ray Diffraction Laboratory, Institute of Geological Sciences, Polish Academy of Sciences and an X-ray Philips PW 3710 diffractometer at the Faculty of Earth Sciences, University of Silesia. Efflorescence phase compositions are given in Table S2.

\section{Gas chromatography}

To assess the variability of gas compositions, several dominating compounds were selected based on previous research (Fabiańska et al. 2013). Molecular compositions of self-heating gases $\left(\mathrm{CH}_{4}, \mathrm{C}_{2} \mathrm{H}_{6}\right.$, $\mathrm{C}_{3} \mathrm{H}_{8}, i \mathrm{C}_{4} \mathrm{H}_{10}, n \mathrm{C}_{4} \mathrm{H}_{10}, \mathrm{C}_{5} \mathrm{H}_{12}, \mathrm{C}_{6} \mathrm{H}_{14}, \mathrm{C}_{7} \mathrm{H}_{16}$, unsaturated hydrocarbons, $\mathrm{CO}_{2}, \mathrm{O}_{2}, \mathrm{H}_{2}, \mathrm{~N}_{2}$ ) were determined on an Agilent 7890A gas chromatograph equipped with a set of columns, and flame ionization (FID) and thermal conductivity (TCD) detectors. This GC is configured to do an extended natural gas analysis up to $\mathrm{C}_{14}$. The analyzer is a three-valve system using three 1/8-inch packed columns $(3 \mathrm{ft}$ Hayesep Q 80/100 mesh, 6 ft Hayesep Q 80/100 mesh, and $10 \mathrm{ft}$ molecular sieve $13 \times 45 / 60 \mathrm{mesh}$ ) and a GSAlumina capillary column $(50 \mathrm{~m} \times 0.53 \mathrm{~mm})$. The system consists of two independent channels. The channel using the FID for the detailed hydrocarbon analysis is a simple gas sampling valve injecting the sample into the GS-Alumina column. The second channel using packed columns is for determination of methane, ethane, and non-hydrocarbon gases. The GC oven was programmed as follows: initial $\mathrm{T}$ of $60{ }^{\circ} \mathrm{C}$ held for $1 \mathrm{~min}$., then to $90{ }^{\circ} \mathrm{C}$ at $10^{\circ} \mathrm{C} / \mathrm{min}$., then to $190{ }^{\circ} \mathrm{C}$ at $20{ }^{\circ} \mathrm{C} / \mathrm{min}$., and finally held for $5 \mathrm{~min}$. The front detector (TCD) was operated at $150{ }^{\circ} \mathrm{C}$, and the back detector (FID) at $250{ }^{\circ} \mathrm{C}$. Helium was used as a carrier gas flowing through the TCD channel at $\mathrm{cm}^{3} \min ^{-1}$ and through the FID channel at $\mathrm{cm}^{3} \min ^{-1}$.

\section{Results and discussion}

General composition of gases

Almost all samples contained gaseous products resulting from the thermal destruction of coal waste organic matter mixed with atmospheric oxygen and nitrogen. Total concentrations of gases show high variability 
related to the sampling site and self-heating stage. Obviously, the highest absolute emissions occur in very active sites such as at the Anna, Wełnowiec, and Rymer Cones, whereas emissions from dumps showing low thermal activity, or none as the Przygórze, are hundreds of times lower (Table S3). In terms of the temperatures measured at sampling sites (Table S2), and of the self-heating stage, the gas samples may be grouped into samples from (1) from sites with no thermal activity, i.e., with no known fire history or where thermal activity has ceased, (2) sites with selfheating ongoing; these subdivide into gases (a) from the initial stage of self-heating, (b) emitted during intense heating, and (c) from sites of waning activity.

Apart from $\mathrm{O}_{2}$ and $\mathrm{N}_{2}$, two further main components are $\mathrm{CH}_{4}$ and $\mathrm{CO}_{2}$, both toxic and regarded as the main greenhouse gases (Kim 2007; EPA 2005). Absolute gas concentration values (Table S3) give information about emission scale, whereas relative percentage compositions show correlations between components. Compared to $\mathrm{CH}_{4}$, all other hydrocarbons appear in much lower amounts (Table S3). Unsaturated hydrocarbons were typically present in lower amounts than were their saturated analogues. To compare the highly variable gas distributions, the following relative percentage concentrations were calculated: (1) The relative percentage compositions of gases present together with atmospheric $\mathrm{N}_{2}$ and $\mathrm{O}_{2}$ (Table 1a, b), (2) relative percentage compositions of organic compounds, including $\mathrm{CH}_{4}$ (Table 2), (3) relative percentage compositions of heavier hydrocarbons, excluding $\mathrm{CH}_{4}$. As there are significant differences in emitted gas compositions between the Upper (US) and Lower Silesia (LS) basins, both are treated separately below.

The typical gas at a site with no thermal activity is dominated by atmospheric $\mathrm{O}_{2}$ and $\mathrm{N}_{2}$ (Tables 1 and S3). Average percentage contents for the US and LS basins are: $\mathrm{N}_{2}=78.6$ and $80.1 \%$ vol., respectively, and $\mathrm{O}_{2}=18.8$ and $20.8 \%$ vol., respectively. Carbon dioxide contents are elevated compared to average atmosphere (0.035\% vol.), namely 1.085 (US) and 0.151 (LS) \% vol. However, at some inactive sites $\mathrm{CO}_{2}$ was absent. The atmospheric gases are accompanied by small amounts of organic compounds, among which, $\mathrm{CH}_{4}(0.0061$ and $0.0040 \%$ vol.) and ethylene $(0.0030$ and $0.0011 \%$ vol.) predominate. Heavier aliphatic hydrocarbons from cis-2-butene to $n$-hexane occur in much lower amounts (0.0001-0.0005\% vol.).

Gases from ongoing self-heating sites show a significant decrease in $\mathrm{O}_{2}$ content, being $<5.5$ times lower than in the atmosphere. Apart from the major atmospheric gases, $\mathrm{CO}_{2}$ is the predominating component, averaging 3.7350 (US) and 5.2447 (LS) \% vol. The organic gases also include $\mathrm{CH}_{4}(1.3233$ (US) and 0.1432 (LS) \% vol.), saturated aliphatic hydrocarbons including ethane, propane, $n$-butane, $n$-pentane, $n$ hexane, $n$-heptane, iso-butane, and iso-pentane, together with unsaturated aliphatic hydrocarbons including ethylene, acetylene, propylene, and transand cis-2-butene. Typically, concentrations decrease with increasing molecular weight but, in some LS gases (S1a, S1d, S2b, S3, and S4a), elevated contents of propane and $n$-butane were noted. In sample A1, the relative content of propane exceeds that of $\mathrm{CH}_{4}$ (Table S3). Thermal activity also results in elevated $\mathrm{H}_{2}$ contents, i.e., 0.2125 (US) and 0.0186 (LS) \% vol. (Table 1b). These values greatly exceed average atmospheric $\mathrm{H}_{2}$ concentrations $(0.0000055 \%$ vol.). The unsaturated hydrocarbons and $\mathrm{H}_{2}$ are pyrolytical products of self-heating; they are common in refinery and coal pyrolysis gases (Saavedra et al. 2013; Speight 2014).

Gas compositions, emission levels, and their potential significance

In the dump emissions, the classes of gases distinguished include (1) main air components, (2) oxygenated compounds $\left(\mathrm{CO}_{2}\right)$, (3) reducing gases $\left(\mathrm{CH}_{4}\right.$ and $\mathrm{H}_{2}$ ), (4) saturated aliphatic hydrocarbons in the range $\mathrm{C}_{2}-\mathrm{C}_{7}$, and (5) unsaturated aliphatic hydrocarbons in the range $\mathrm{C}_{2}-\mathrm{C}_{4}$.

\section{Carbon dioxide}

Apart from oxygen and nitrogen, the predominating component of all gases from sites with ongoing thermal activity is $\mathrm{CO}_{2}$ present in amounts $<$ several relative percent (vol.). Apart from its significance as a greenhouse gas, $\mathrm{CO}_{2}$ is also toxic. The normal $\mathrm{CO}_{2}$ concentration outdoors is ca $300-350 \mathrm{ppm}$ or $0.54-0.63 \mathrm{~g} / \mathrm{m}^{3}$ (Killops and Killops 2005). The level still comfortable indoors is $600-800 \mathrm{ppm}$ $\left(1.08-1.44 \mathrm{~g} / \mathrm{m}^{3}\right)$. The highest $\mathrm{CO}_{2}$ concentration registered at thermally active sites was $291.5211 \mathrm{~g} /$ 


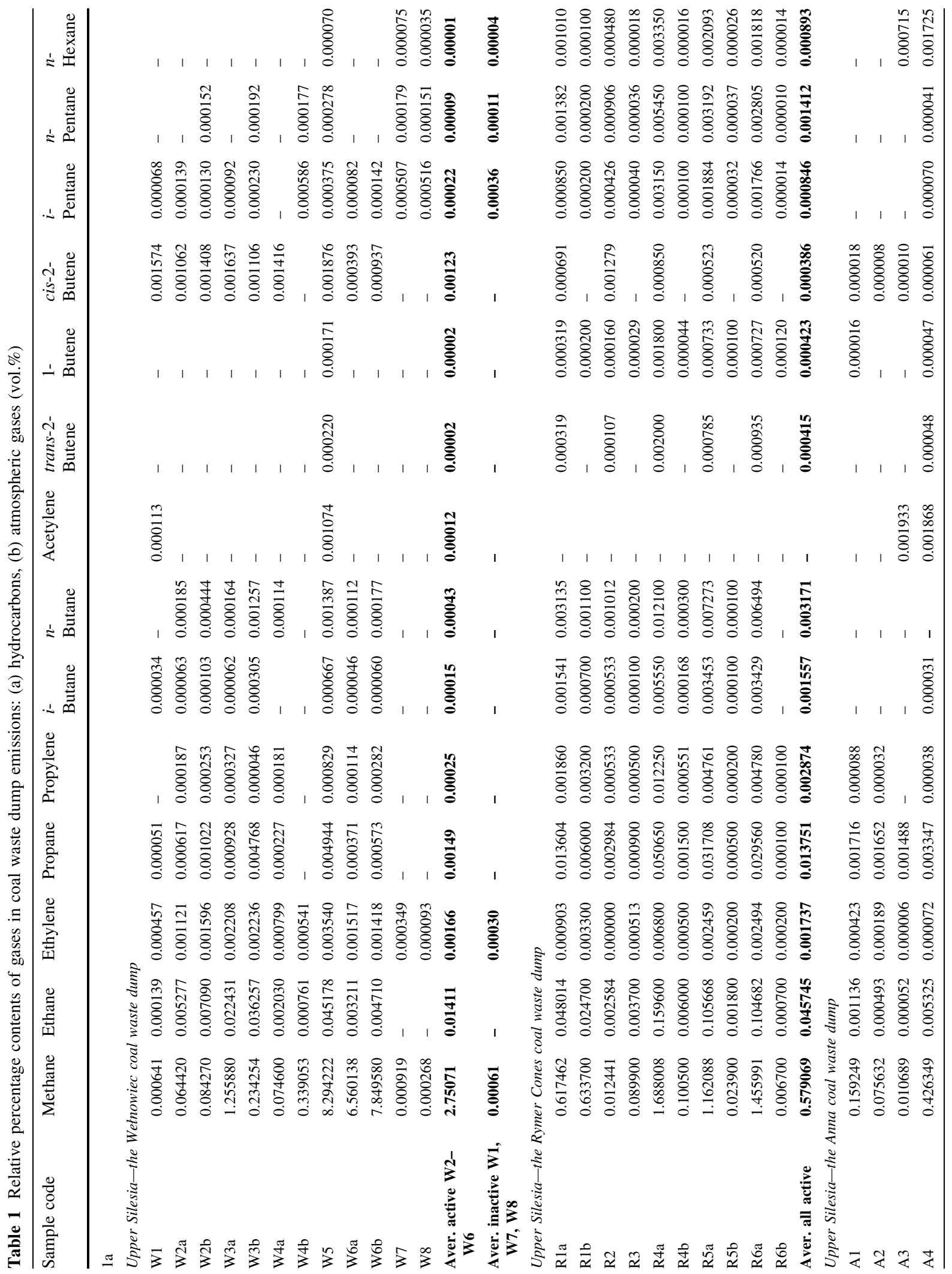




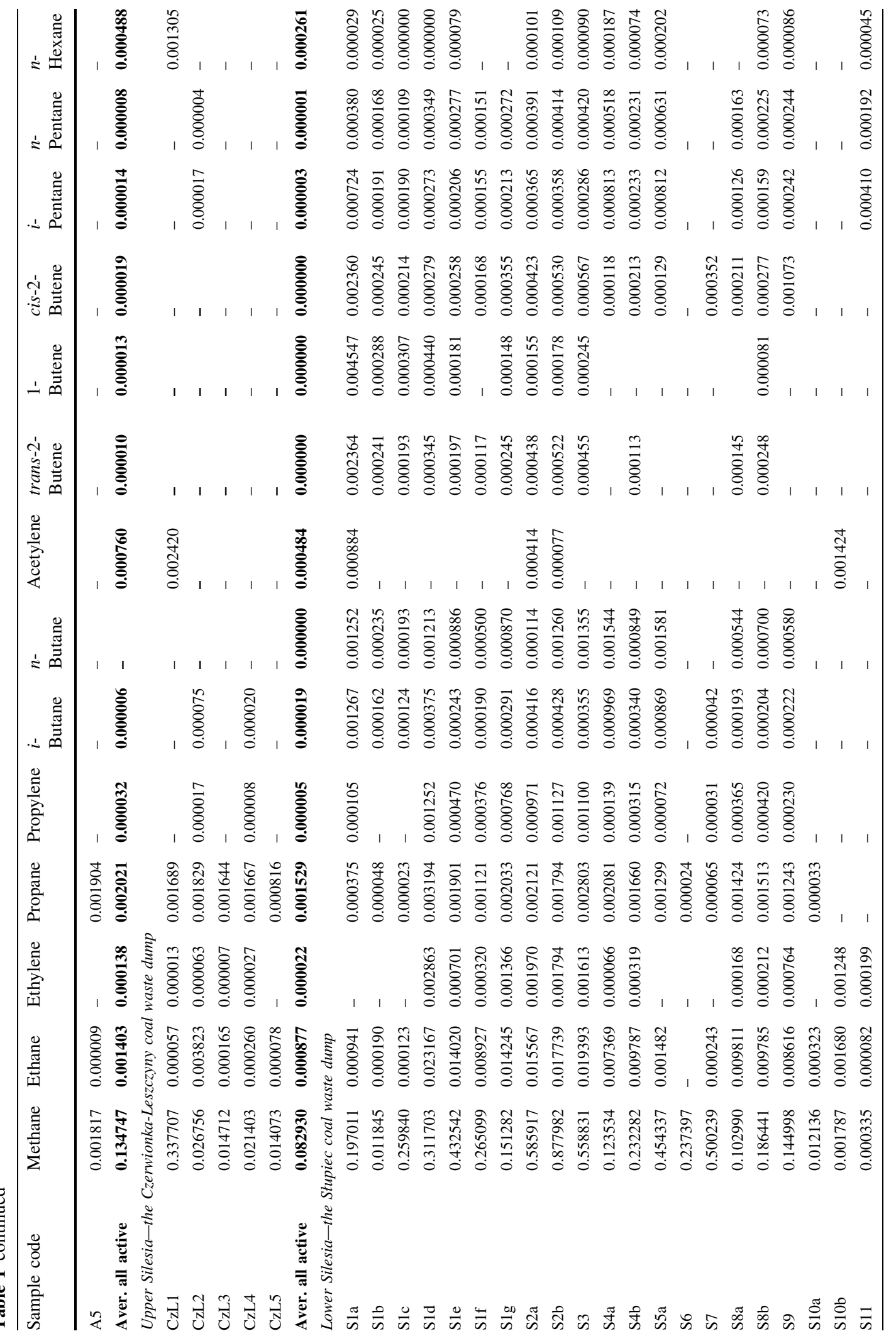




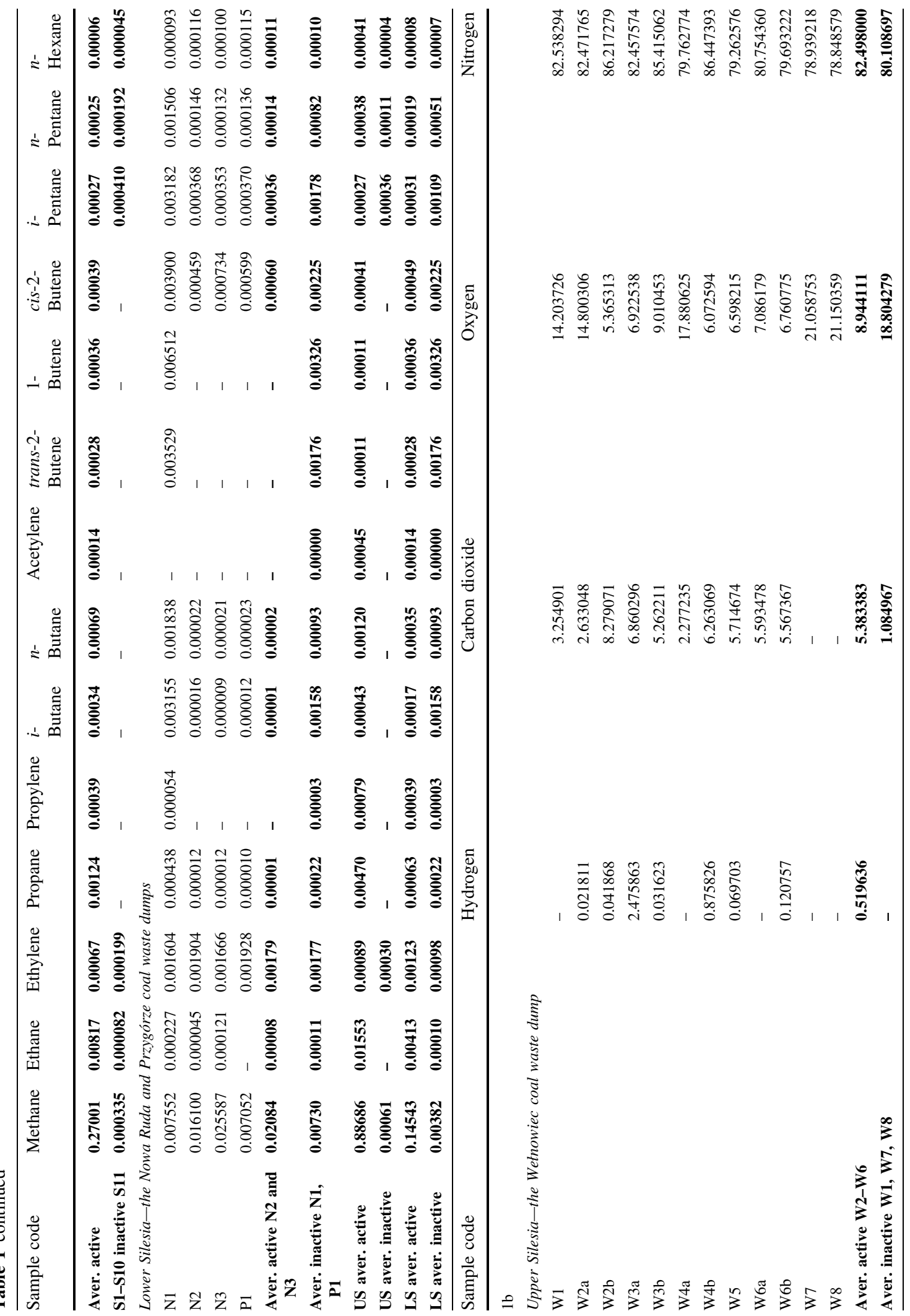




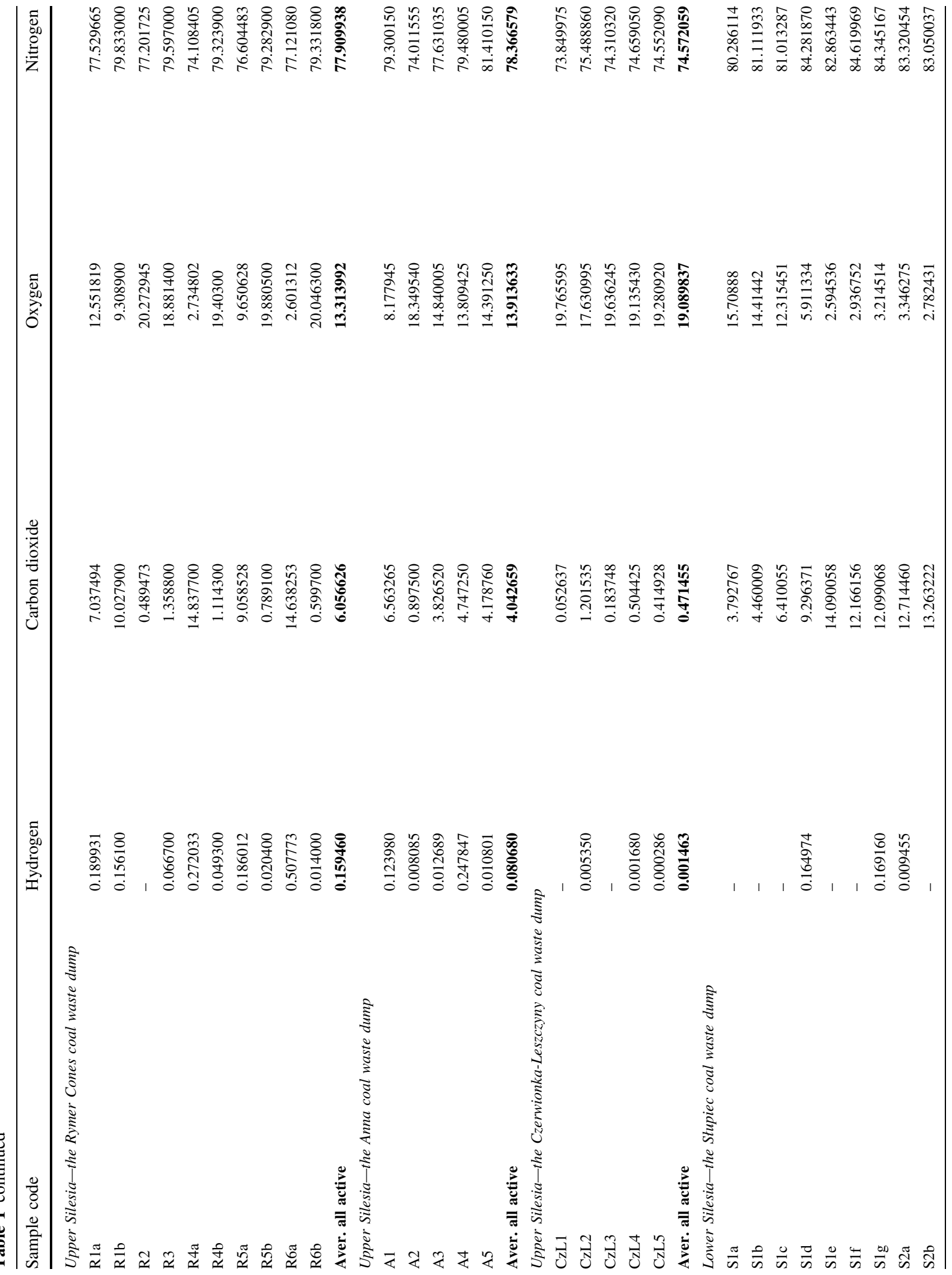




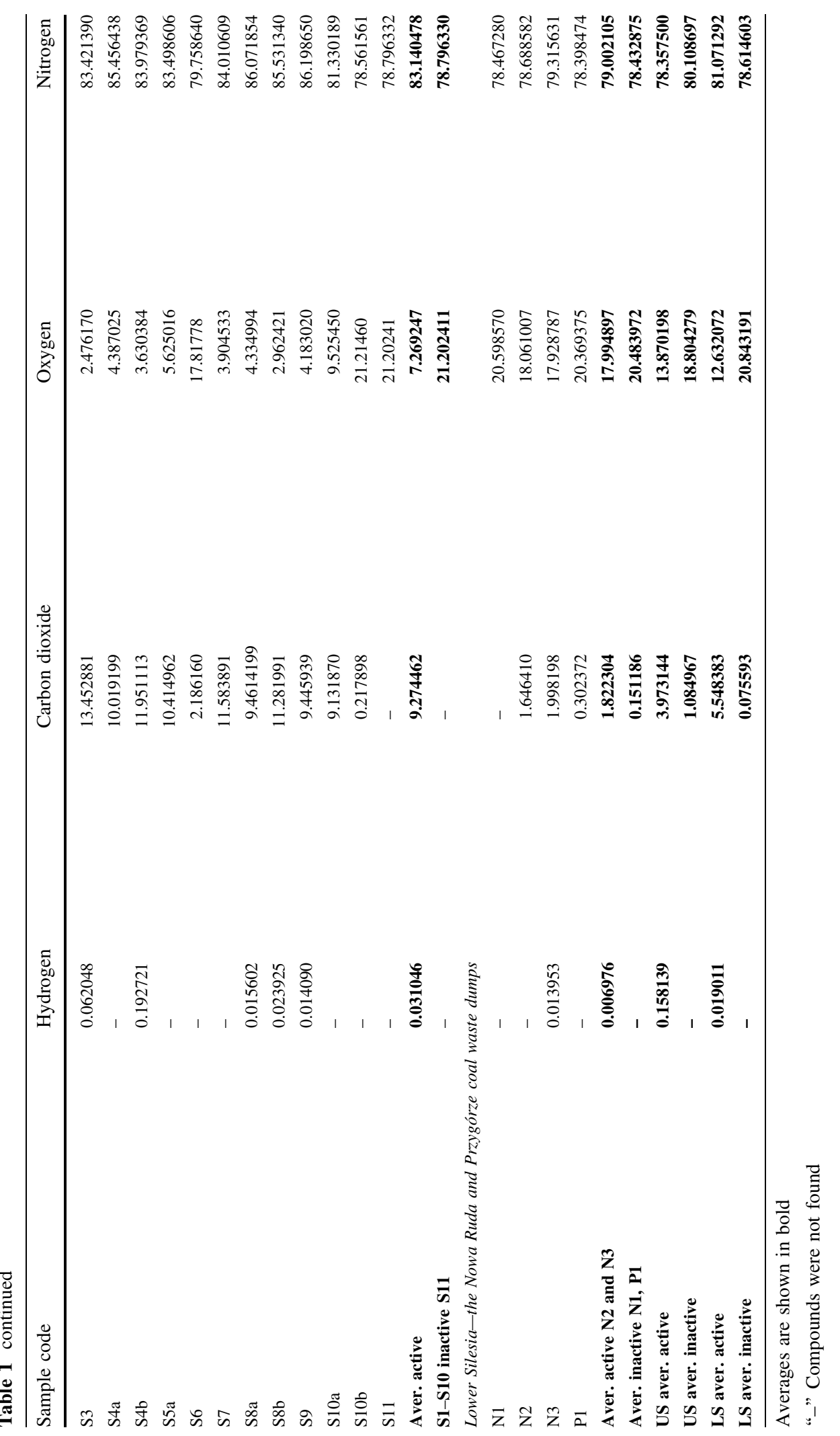




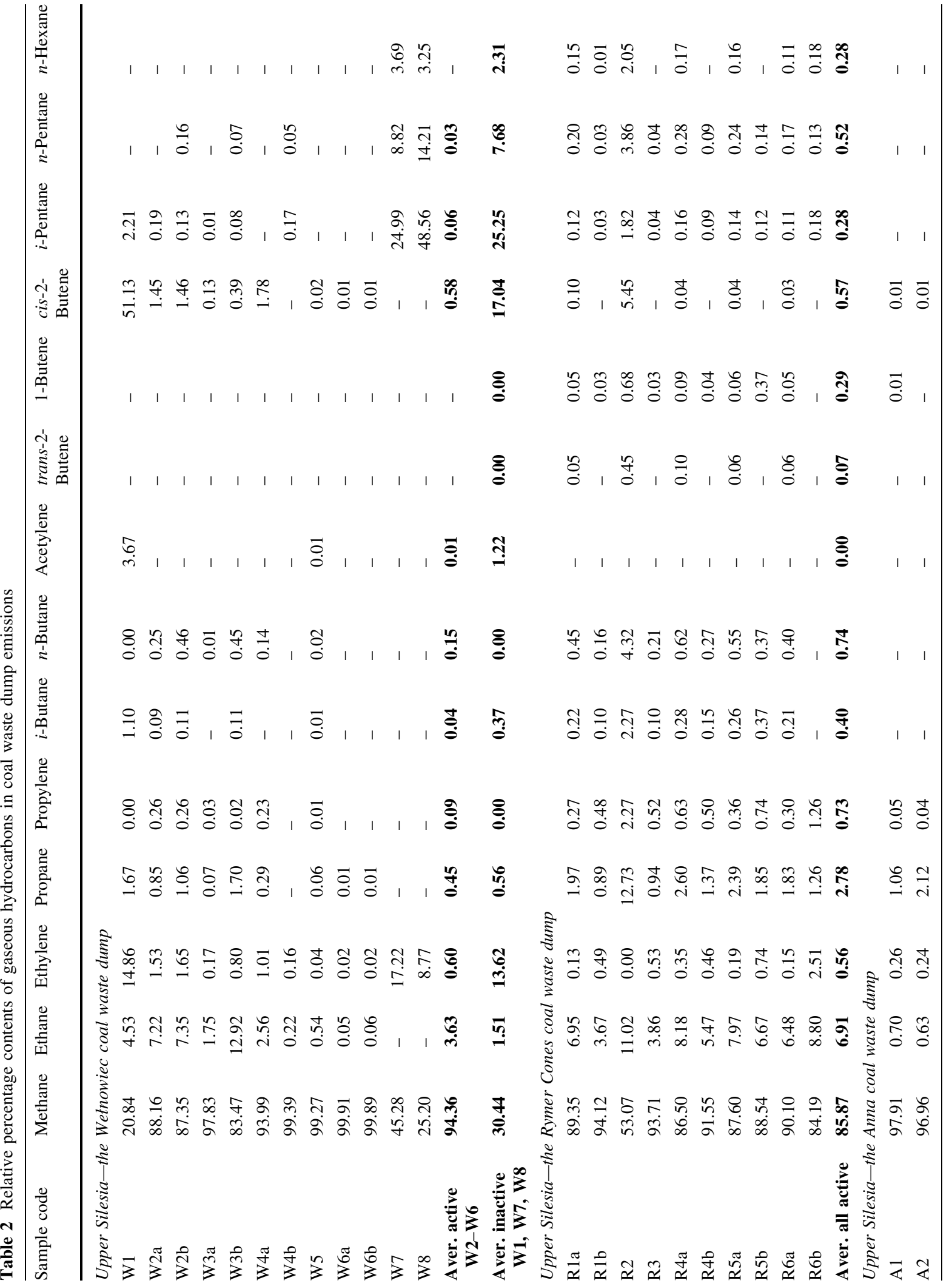




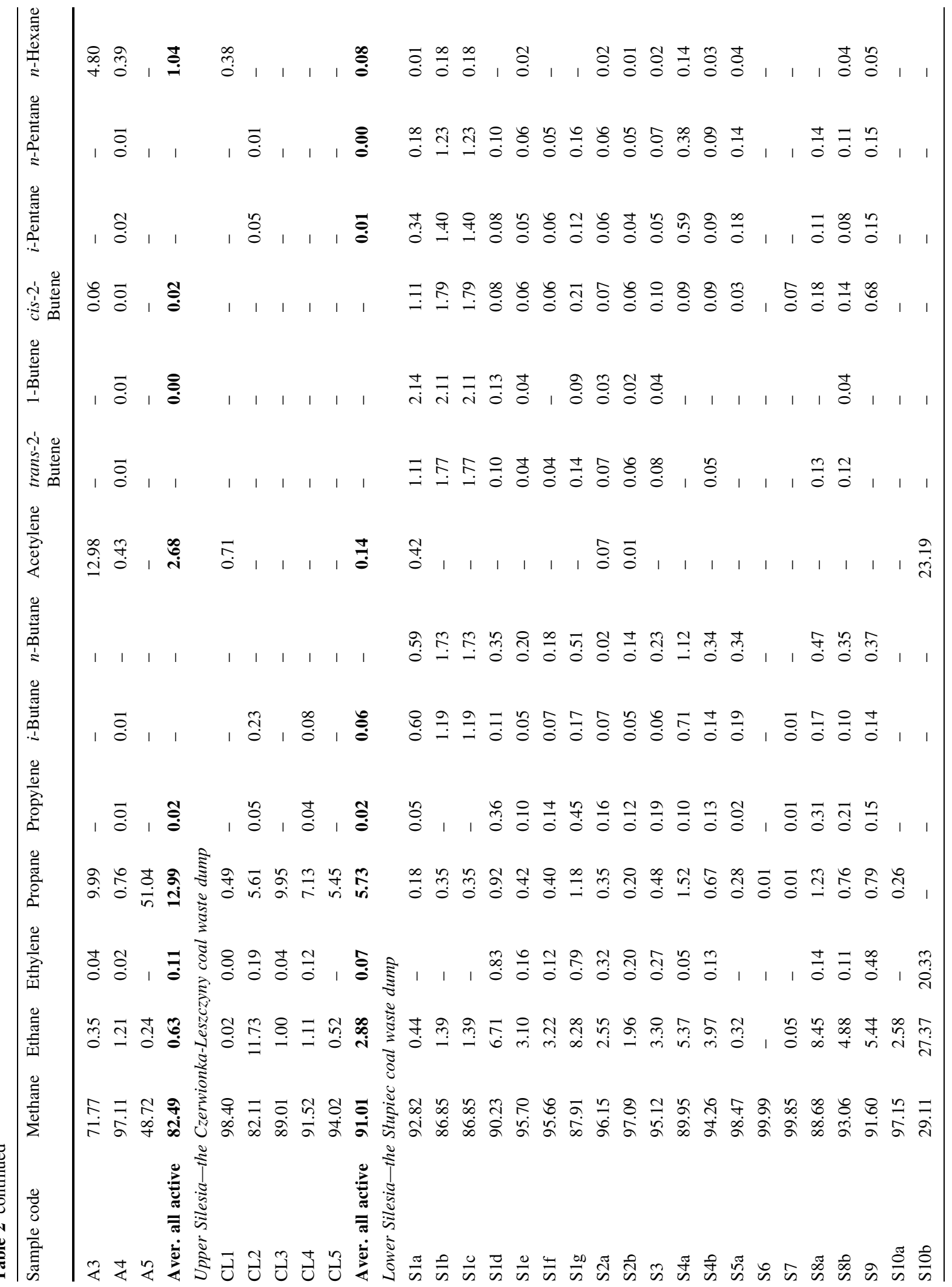




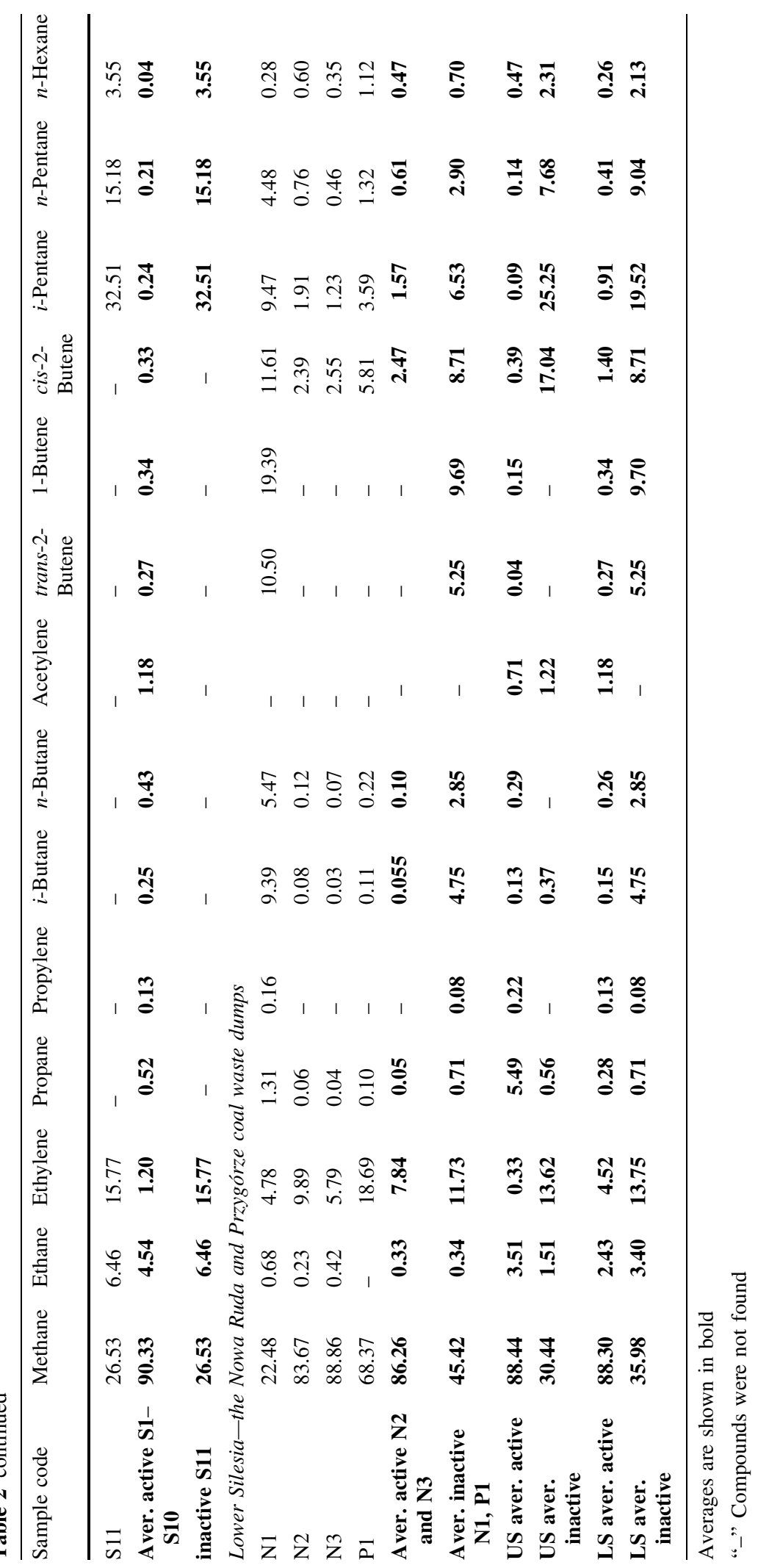


Fig. 3 Correlation between $\mathrm{CO}_{2}$ and $\mathrm{CH}_{4}($ rel.\%) contents in coal waste dump gases

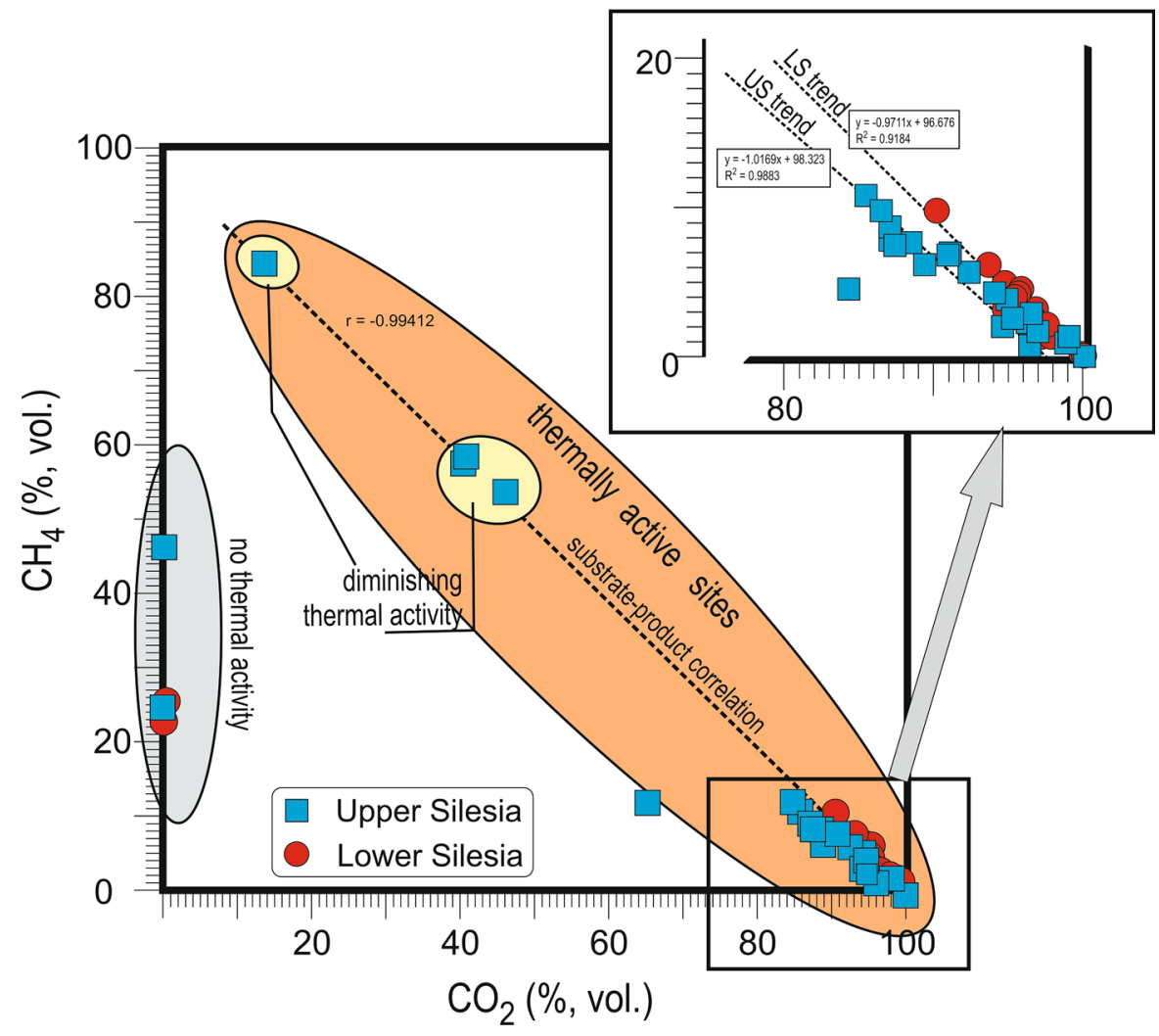

$\mathrm{m}^{3}$ or $161,666 \mathrm{ppm}$. This is $>500$ times the normal atmospheric level, and $>1.5$ times the level (100 $000 \mathrm{ppm}$ ) that leads to loss of consciousness and, ultimately, death (Brake and Bates 1999). This will happen even when $\mathrm{O}_{2}$ is at the normal atmospheric level, not the case in coal waste dump gas characterized by a significant decrease in $\mathrm{O}_{2}$ (Tables 1 and S3).

Carbon dioxide emissions from sites presently inactive but active in the past are 21.3167 (US) and 4.4556 (LS) g/ $/ \mathrm{m}^{3}$ (aver. $12.8862 \mathrm{~g} / \mathrm{m}^{3}$; Table S3). Thus, $\mathrm{CO}_{2}$ emissions from inactive dumps at ca $7000 \mathrm{ppm}$ are close to levels at which adverse health effects might be expected (10 000 ppm; ACGIH 1999; Pauluhn 2016). Moreover, $\mathrm{CO}_{2}$ is considered to aggravate the toxicity of $\mathrm{CO}$ when both are present in the same gas (Pauluhn 2016). This suggests that the use of apparently inactive coal waste dumps as recreation sites may involve harmful exposure levels.

Carbon dioxide predominance in coal waste selfheating gases is common (Yan et al. 2003; Kim 2007; Carras et al. 2009; Hower et al. 2009; O'Keefe et al. 2010), with contents increasing significantly with increasing thermal activity. $\mathrm{CO}_{2}$ also shows inverse correlations with $\mathrm{CH}_{4}$ (below) when the emitted gas results from self-heating sites are recalculated to relative percentages, omitting $\mathrm{N}_{2}$ and $\mathrm{O}_{2}$ (Table 1; Fig. 3).

\section{Methane}

Methane predominates among organic compounds, occurring in amounts $>80 \%$, in some cases, $<$ $99.91 \%$ rel. in sites of current thermal activity (Table 1a). It may be $\mathrm{CH}_{4}$ that was in coal pores as most US and LS coal mines are methane-rich (Kotarba 2001; Kędzior 2009), but is more likely related to organic matter cracking (Grossman et al. 1994; Davidi et al. 1995; Fabiańska et al. 2013). Methane is the only hydrocarbon occurring naturally in the atmosphere (1.6-1.8 ppm; Schneising et al. 2014; Dlugokencky 2016). This methane comes from the biosphere, e.g., wetlands, methanogenic microorganisms, and natural fires, and the geosphere, e.g., natural gas, volcanic eruptions, permafrost, or clathrates. Agriculture and the fossil fuel industry are responsible for the global increase from the pre-industrial value of 722 to 
$1800 \mathrm{ppb}$ in 2016 (Schneising et al. 2014). Methane from shale gas production, measured over three shale regions in the USA, has increased the atmospheric level by ca $2.0 \mathrm{ppm}$, i.e., $0.0013 \mathrm{~g} / \mathrm{m}^{3}$ (Peischl et al. 2015). The highest $\mathrm{CH}_{4}$ emissions from the Silesian dumps, recorded in Wełnowiec dump (W4b, W5, and W6), were a few tens $\mathrm{g} / \mathrm{m}^{3}$. There are two possible explanations for these high $\mathrm{CH}_{4}$ levels, namely (i) the compound was released from still-decaying urban wastes originally dumped there, or (ii) that, during their combustion, the top cover of coal waste limited $\mathrm{CH}_{4}$ oxygenation. Conspicuously, lower $\mathrm{CH}_{4}$ emissions (from 0.1 to several $\mathrm{g} / \mathrm{m}^{3}$ ) from other Silesian dumps are still 1000 times higher than atmospheric levels (Table S3).

Even at sites where fire was extinguished years ago, and ambient temperatures prevail, $\mathrm{CH}_{4}$ was recorded with emissions averaging 0.004363 (US) and 0.05163 (LS) $\mathrm{g} / \mathrm{m}^{3}$ (6.7 and $78.9 \mathrm{ppm}$, respectively). These levels are 4-40 times atmospheric levels. However, they pale in comparison with thermally active sites where $\mathrm{CH}_{4}$ emissions average 6.350585 (US) and 1.031258 (LS) g/m $\mathrm{m}^{3}$ (9704.5 and $1575.9 \mathrm{ppm}$, respectively). Carras et al. (2009), investigating emissions from Australian coal wastes without visible signs of combustion, found no methane but elevated $\mathrm{CO}_{2}$ concentrations. It is possible that, in Silesia, when selfheating has ended, $\mathrm{CH}_{4}$ continues to be emitted from pores, particularly if combustion conditions were reducing and oxygenation incomplete. Even more surprising is the $\mathrm{CH}_{4}$ presence at the reference site where heating never occurred (S11). Here, $\mathrm{CH}_{4}$ may be a biogenic product of microorganisms living on coal waste. It is usually considered that methanogens live in wet anaerobic conditions not seen in coal waste dumps (Tung et al. 2005). They are, however, found in extremely dry and oxic soils (Peters and Conrad 1995).

These data indicate that coal waste dumps, thermally active or not, should be considered a significant source of methane in industrial regions such as Silesia where ca 40 million tonnes of coal waste are produced annually (Korban 2011). The global significance of methane and $\mathrm{CO}_{2}$ fluxes from coal waste dumps may be underestimated.

Carbon dioxide and methane relationship

Omitting $\mathrm{N}_{2}$ and $\mathrm{O}_{2}$, as in Table 1, a clear relationship between the relative contents of $\mathrm{CH}_{4}$ and $\mathrm{CO}_{2}$ reveals an overall substrate-product relationship for thermally active sites $(r=-0.99$; Fig. 3$)$. This indicates that just after its release, $\mathrm{CH}_{4}$ oxidizes to $\mathrm{CO}_{2}$ within the dumps. The small difference in the correlation in the individual basins may relate to differences in the characteristics of the coal waste organic matter, e.g., rank, depositional environment or storage environment. Rank seems to be the more influential factor as two Upper Silesian dumps, Wełnowiec and Rymer Cones, correlate well despite their different shape, history, and size. The same substrate-product relationship exists between $\mathrm{O}_{2}$ and $\mathrm{CO}_{2}$ for both the US and LS basins ( $r=-0.89$ and -0.98 , respectively) and between values of oxygen decrease (OD) and $\mathrm{CO}_{2}$ relative contents $(r=0.87$ and 0.93 , respectively; Fig. 3).

Relative percentage contents of $\mathrm{CO}_{2}$ and $\mathrm{CH}_{4}$ seem to correlate with self-heating stage. Initial-stage sites, marked by organic efflorescences (W2 and W3), and sites with ongoing heating show no significant differences and $\mathrm{CO}_{2}$ production prevails (Table $\mathrm{S} 2$ ). However, where fire is beginning to wane (W5 and W6) $\mathrm{CO}_{2}$ relative contents decrease, whereas those of $\mathrm{CH}_{4}$ increase. $\mathrm{No} \mathrm{CO}_{2}$ is expelled in thermally inactive sites.

Saturated aliphatic hydrocarbons and unsaturated aliphatic hydrocarbons

Saturated aliphatic hydrocarbons occur in the range from ethane to heptane though, in most gases, $\mathrm{C}_{6}$ and $\mathrm{C}_{7}$ hydrocarbons are absent. Both normal and branched compounds occur. Apart from W1, W8, $\mathrm{R} 1-4, \mathrm{~S} 1 \mathrm{a}-\mathrm{c}, \mathrm{S} 6$, and S11, ethane predominates in the saturated gas fraction.

Unsaturated hydrocarbons comprise alkenes in the range $\mathrm{C}_{2}-\mathrm{C}_{4}$ and acetylene. Due to its relatively high reactivity, acetylene was found in only a few samples (W1, W5, A3, A4, CzL1, S1a, and S10b). Other compounds with triple bonds are absent. Among unsaturated hydrocarbons, ethylene dominates though typically comprising $<1.0 \%$ of total organic compounds. However, ethylene contents increase significantly in sites showing particularly elevated temperatures, e.g., to $>25 \%$ of all organic compounds in W3b $\left(t=690{ }^{\circ} \mathrm{C}\right.$ at $\left.50 \mathrm{~cm}\right)$. Contents of all other unsaturated hydrocarbons decrease with increasing carbon atom numbers in a molecule. Surprisingly, ethylene is also a significant component $(<$ several \%) 
of total organic components in gases at sites of waning thermal activity, e.g., W1, W7, W8, S1b, S11, and N1 with measured temperatures close to ambient. Possibly, as with methane, ethylene is degassed from pores even after self-heating ends or it is produced by bacteria growing on coal waste surfaces; many soil bacteria species, e.g., many chemolithotrophs, can produce ethylene (Nagahama et al. 1992).

Ethylene predominates over ethane in some once thermally active sites (W1, N1, N2, N3, and P1) where temperatures have waned to near ambient. Ethylene together with $\mathrm{CO}_{2}$ can markedly influence vegetation on coal waste dumps. Plants use $\mathrm{CO}_{2}$ to build tissues, and ethylene is a growth hormone accelerating flowering and fruit maturation (Johnson and Ecker 1998). The gigantism of the lush vegetation on self-heating dumps (Ciesielczuk et al. 2015) may thus be explained. Other unsaturated hydrocarbons present in much lower amounts include propylene and $c i s$ - and trans-2-butene. Though with toxicities less than those of $\mathrm{CO}_{2}$ and $\mathrm{CH}_{4}$, these are neurotoxins that, inhaled, cause dizziness, tachycardia, impaired coordination, and disorientation (Broussard 1999).

Hydrogen and unsaturated hydrocarbons

Hydrogen was found only at thermally active sites, despite being a product of low-temperature oxidation of bituminous coals (Grossman et al. 1993; Czechowski et al. 2007). The inverse correlation of unsaturated hydrocarbons and free hydrogen indicates that double bonds are saturated in self-heating zones.

Assessment of thermal activity level using gas ratios

To assess thermal activity in the coal waste dumps, and to compare its development in different dumps, the following ratios were calculated (Table 3 ).

(1) Oxygen decrease (OD) calculated as $\mathrm{N}_{2} / \mathrm{O}_{2}$ ratio to the ratio of these same gases in the atmosphere (3.35; vol.: vol.). $\mathrm{N}_{2}$ is assumed to be inert; it neither reacts with coal waste nor is released. The $\mathrm{OD}$ value reflects $\mathrm{O}_{2}$ consumption during heating.

(2) The ratio of saturated to unsaturated hydrocarbons $(\mathrm{S} / \mathrm{UnS})$. It is assumed that unsaturated hydrocarbons are the products of organic matter macromolecule cracking. This parameter reflects the thermal destruction of organic matter.

(3) Carbon dioxide/methane, the ratio of two major components of gas emissions from coal waste dumps

\section{Oxygen decrease (OD) ratio}

Oxygen decrease is caused by oxidation of organic matter due to self-heating. Thus, the OD value reflects the process intensity; the higher the value, the more intense the self-heating. OD values are arbitrarily designated as follows: 1.0-1.7 (low self-heating or none), 1.8-3.0 (moderate heating), $>3.0$ (intense heating).

Samples with very low OD values are W1, W2a, W4a, W7, W8, all Rymer Cones gases taken in the later series (R2-R4b, R5b, R6b), and A2-5, CzL1-5, S1a-c, S 6, S10b, S11, P1, and N1-3. Moderate values characterize only six samples, i.e., W3b, R1a and b, R5a, A1, and S10a. The highest values pertain to W2b, W3a, W4b, W5, W6a-b, R4a, R6a, S1d-g, S2-5, and S7-9 (Table 3). OD correlates with $>2.0 \%$ (vol.) contents of $\mathrm{CO}_{2}$ in the total gas composition; the substrate-product relationship is confirmed by inverse correlations ( $r=-0.89$ for US and -0.98 for LS) of relative contents (vol.) of $\mathrm{CO}_{2}$ versus $\mathrm{O}_{2}$ and positive correlations ( $r=0.87$ for US and -0.93 for LS) between $\mathrm{OD}$ values and $\mathrm{CO}_{2}$ relative contents (Fig. 4). The particularly high correlations $(r=1.00)$ between $\mathrm{OD}$ and $\mathrm{CO}_{2}$ for the Wełnowiec gas samples probably reflect firefighting activity; during sampling, the dump was opened to cool burning waste, increasing $\mathrm{O}_{2}$ access, and intensifying combustion and elevating temperatures $\left(<700{ }^{\circ} \mathrm{C}\right)$. The strong correlation indicates that most $\mathrm{O}_{2}$ was consumed by $\mathrm{CO}_{2}$ production with other oxides playing only a very minor role.

Higher OD values generally characterize sites with temperatures $>70{ }^{\circ} \mathrm{C}$, the self-heating threshold temperature (Gumińska and Różański 2005). Below, only mild organic matter oxidation occurs. If the threshold is breached, a rapid further temperature increase leads to self-heating and, potentially, opens fire. Alternatively, slow cooling occurs and, in time, organic matter weathering. The initial stage of self-heating lasting several days is difficult to recognize; there are 
Table 3 Component ratios characterizing variability of waste dump emissions

\begin{tabular}{|c|c|c|c|c|c|}
\hline Sample code & $\mathrm{N}_{2} / \mathrm{O}_{2}$ (vol.) & $\mathrm{OD}^{\mathrm{a}}$ & $\mathrm{CO}_{2} / \mathrm{CH}_{4}$ (vol.) & Sat/Unsat.HC & $\overline{\mathrm{CH}_{4} / \text { all } \mathrm{HC}^{\mathrm{c}}}$ \\
\hline \multicolumn{6}{|c|}{ Upper Silesia-the Wetnowiec coal waste dump } \\
\hline W1 & 5.81 & 1.73 & 5074.30 & 0.14 & 0.26 \\
\hline W2a & 5.57 & 1.66 & 40.87 & 2.65 & 7.45 \\
\hline $\mathrm{W} 2 \mathrm{~b}$ & 16.07 & 4.80 & 98.24 & 2.74 & 6.91 \\
\hline W3a & 11.91 & 3.56 & 5.46 & 5.68 & 45.10 \\
\hline $\mathrm{W} 3 \mathrm{~b}$ & 9.48 & 2.83 & 22.46 & 12.69 & 5.05 \\
\hline W4a & 4.46 & 1.33 & 30.53 & 0.99 & 15.65 \\
\hline $\mathrm{W} 4 \mathrm{~b}$ & 14.24 & 4.25 & 18.47 & 2.82 & 164.27 \\
\hline W5 & 12.01 & 3.59 & 0.69 & 6.86 & 136.85 \\
\hline W6a & 11.40 & 3.40 & 0.85 & 1.89 & 1122.26 \\
\hline W6b & 11.79 & 3.52 & 0.71 & 2.15 & 945.73 \\
\hline W7 & 3.75 & 1.12 & 0.00 & 2.18 & 0.83 \\
\hline W8 & 3.73 & 1.11 & 0.00 & 7.53 & 0.34 \\
\hline Aver. active W2-W6 & 10.77 & 3.22 & 24.25 & 4.27 & 272.14 \\
\hline $\begin{array}{l}\text { Aver. inactive W1, } \\
\text { W7, W8 }\end{array}$ & 4.43 & 1.32 & 1691.43 & 3.28 & 0.48 \\
\hline \multicolumn{6}{|c|}{ Upper Silesia-the Rymer Cones coal waste dump } \\
\hline R1a & 6.18 & 1.84 & 11.40 & 156.35 & 23.38 \\
\hline $\mathrm{R} 1 \mathrm{~b}$ & 8.58 & 2.56 & 15.82 & 4.91 & 16.00 \\
\hline $\mathrm{R} 2$ & 3.81 & 1.14 & 39.34 & 10.28 & 1.13 \\
\hline $\mathrm{R} 3$ & 4.22 & 1.26 & 15.11 & 4.79 & 14.89 \\
\hline $\mathrm{R} 4 \mathrm{a}$ & 27.10 & 8.09 & 8.79 & 81.63 & 6.25 \\
\hline $\mathrm{R} 4 \mathrm{~b}$ & 4.09 & 1.22 & 11.09 & 7.47 & 10.83 \\
\hline $\mathrm{R} 5 \mathrm{a}$ & 7.94 & 2.37 & 7.80 & 142.38 & 7.01 \\
\hline $\mathrm{R} 5 \mathrm{~b}$ & 3.99 & 1.19 & 33.02 & 5.19 & 7.72 \\
\hline R6a & 29.65 & 8.85 & 10.05 & 170.05 & 9.02 \\
\hline R6b & 3.96 & 1.18 & 89.51 & 2.00 & 5.33 \\
\hline Aver. all active & 9.95 & 2.97 & 24.19 & 58.51 & 10.16 \\
\hline \multicolumn{6}{|c|}{ Upper Silesia—the Anna coal waste dump } \\
\hline A1 & 9.70 & 2.89 & 41.21 & 5.23 & 46.87 \\
\hline $\mathrm{A} 2$ & 4.03 & 1.20 & 11.87 & 9.38 & 31.85 \\
\hline A3 & 5.23 & 1.56 & 358.00 & 1.16 & 2.54 \\
\hline A4 & 5.76 & 1.72 & 11.13 & 4.94 & 33.65 \\
\hline A5 & 5.66 & 1.69 & 2299.29 & - & 0.95 \\
\hline Aver. all active & 6.08 & 1.81 & 544.30 & 4.14 & 23.17 \\
\hline \multicolumn{6}{|c|}{ Upper Silesia-the Czerwionka-Leszczyny coal waste dump } \\
\hline CzL1 & 3.74 & 1.12 & 0.16 & 1.25 & 61.58 \\
\hline CzL2 & 4.28 & 1.28 & 44.91 & 72.29 & 4.59 \\
\hline CzL3 & 3.78 & 1.13 & 12.49 & 245.86 & 8.10 \\
\hline CzL4 & 3.90 & 1.16 & 23.57 & 55.22 & 10.80 \\
\hline CzL5 & 3.87 & 1.15 & 29.48 & - & 15.73 \\
\hline Aver. all active & 3.91 & 1.17 & 22.12 & 74.92 & 20.16 \\
\hline \multicolumn{6}{|c|}{ Lower Silesia-the Stupiec coal waste dump } \\
\hline S1a & 5.11 & 1.53 & 19.25 & 0.48 & 12.94 \\
\hline S1b & 5.63 & 1.68 & 376.54 & 1.32 & 6.61 \\
\hline
\end{tabular}


Table 3 continued

\begin{tabular}{|c|c|c|c|c|c|}
\hline Sample code & $\mathrm{N}_{2} / \mathrm{O}_{2}$ (vol.) & $\mathrm{OD}^{\mathrm{a}}$ & $\mathrm{CO}_{2} / \mathrm{CH}_{4}$ (vol.) & Sat/Unsat.HC & $\overline{\mathrm{CH}_{4} / \text { all } \mathrm{HC}^{\mathrm{c}}}$ \\
\hline $\mathrm{S} 1 \mathrm{c}$ & 5.63 & 1.68 & 376.54 & 1.32 & 6.61 \\
\hline S1d & 14.26 & 4.26 & 29.82 & 5.52 & 9.24 \\
\hline S1e & 31.94 & 9.53 & 32.57 & 9.74 & 22.27 \\
\hline S1f & 28.81 & 8.60 & 45.89 & 11.26 & 22.05 \\
\hline S1g & 26.24 & 7.83 & 79.98 & 6.22 & 7.27 \\
\hline $\mathrm{S} 2 \mathrm{a}$ & 24.90 & 7.43 & 21.70 & 4.36 & 24.99 \\
\hline $\mathrm{S} 2 \mathrm{~b}$ & 29.85 & 8.91 & 15.11 & 5.23 & 33.35 \\
\hline $\mathrm{S} 3$ & 33.69 & 10.06 & 24.07 & 6.20 & 19.48 \\
\hline $\mathrm{S} 4 \mathrm{a}$ & 19.48 & 5.81 & 81.10 & 41.71 & 8.95 \\
\hline $\mathrm{S} 4 \mathrm{~b}$ & 23.13 & 6.91 & 51.45 & 13.73 & 16.44 \\
\hline S5a & 14.84 & 4.43 & 22.92 & 34.15 & 64.19 \\
\hline S6 & 4.48 & 1.34 & 9.21 & - & 9966.66 \\
\hline S7 & 21.52 & 6.42 & 23.16 & 0.91 & 682.29 \\
\hline S8a & 19.86 & 5.93 & 91.87 & 13.80 & 7.83 \\
\hline $\mathrm{S} 8 \mathrm{~b}$ & 28.87 & 8.62 & 60.51 & 10.23 & 13.42 \\
\hline S9 & 20.61 & 6.15 & 65.15 & 5.43 & 10.90 \\
\hline S10a & 8.54 & 2.55 & 752.45 & - & 34.12 \\
\hline S10b & 3.70 & 1.11 & 121.81 & 0.63 & 0.41 \\
\hline S11 & 3.72 & 1.11 & 0.00 & 3.66 & 0.36 \\
\hline Aver. active S1-S10 & 18.55 & 5.54 & 115.06 & 8.61 & $\mathbf{5 4 8 . 5 0}$ \\
\hline Inactive S11 & 3.72 & 1.11 & 0.00 & 3.66 & 0.36 \\
\hline \multicolumn{6}{|c|}{ Lower Silesia-the Nowa Ruda and Przygórze coal waste dumps } \\
\hline N1 & 3.81 & 1.14 & 0.00 & 0.67 & 0.29 \\
\hline $\mathrm{N} 2$ & 4.36 & 1.30 & 102.26 & 0.33 & 5.12 \\
\hline N3 & 4.42 & 1.32 & 78.09 & 0.34 & 7.98 \\
\hline $\mathrm{P} 1$ & 3.85 & 1.15 & 42.87 & 0.29 & 2.16 \\
\hline Aver. active N2 and N3 & 4.39 & 1.31 & 90.18 & 0.34 & 6.55 \\
\hline Aver. inactive N1, P1 & 3.83 & 1.14 & 21.44 & 0.48 & 1.22 \\
\hline US aver. active & 7.68 & 2.29 & 153.72 & 35.46 & 81.41 \\
\hline US aver. inactive & 4.43 & 1.32 & 1691.43 & 3.28 & 0.477 \\
\hline LS aver. active & 11.47 & 3.42 & 102.62 & 4.47 & 277.53 \\
\hline LS aver. inactive & 3.78 & 1.13 & 10.72 & 2.07 & 0.79 \\
\hline
\end{tabular}

Averages are shown in bold

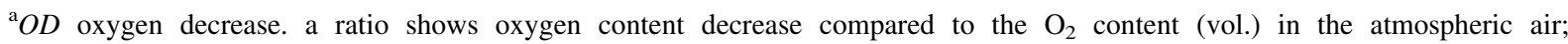
$\mathrm{OD}=3.35 \times \mathrm{N}_{2} / \mathrm{O}_{2}$ content in a gas sample, where 3.35 is the value of atmospheric ratio of $\mathrm{N}_{2} / \mathrm{O}_{2}$ (vol.)

${ }^{\mathrm{b}} \mathrm{Sat} / \mathrm{UnsatHC}=\mathrm{a}$ ratio of a sum of all saturated $\mathrm{C}_{2}-\mathrm{C}_{7}$ hydrocarbons to a sum of all unsaturated hydrocarbons

${ }^{\mathrm{c}} \mathrm{CH}_{4} / \mathrm{all} \mathrm{HC}=$ a ratio of methane content to a sum of all hydrocarbons

“_" Compounds were not found

few external signs. However, it is revealed by elevated $\mathrm{CO}_{2}$ in dump gases and decreased $\mathrm{O}_{2}$ (Tabor 2002).
Saturated to unsaturated hydrocarbons ratio (S/ $\mathrm{UnS}$ )

Values of this parameter reflect the predominance of saturated hydrocarbons in all samples apart from W3b, W4a ( 1.0), NR1-4, NRS1a, NRS7, and NRS10b 


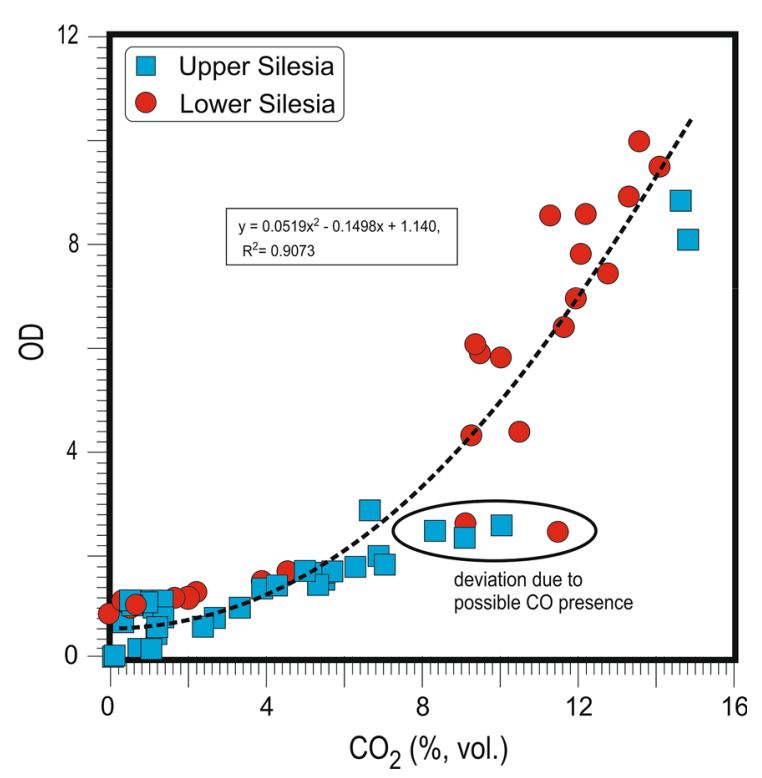

Fig. 4 Correlation between oxygen decrease (OD) composition compared to atmospheric $\mathrm{O}_{2}$ content and content (rel.\%) of $\mathrm{CO}_{2}$ in waste dump gas

(Table 3). At sites without thermal activity, unsaturated hydrocarbons were often absent. In others, the pattern is more complex as self-heating releases hydrocarbons of both types together. High S/UnS values as in $\mathrm{W} 3 \mathrm{c}$ tend to be associated with the highest temperatures, as are higher OD values. The Rymer Cones gases sampled in 2011 and 2015 differ in their $\mathrm{S} / \mathrm{UnS}$ values; the latter have lower values due to comparatively lesser expulsion of saturated hydrocarbons.

Differences in self-heating activity and its dynamics between Upper and Lower Silesia coal waste dumps

There are three factors which should be considered as influencing gas composition: (1) temperature, (2) the stage of self-heating (initial, ongoing, or waning), and (3) characteristics of coal wastes organic matter and minerals. Differences in the chemistry of gas emitted from dumps in LS and US are related to all three factors, but their relative importance varies.

At the time of sampling, at the LS sites, only mild thermal activity prevailed with temperatures $<70{ }^{\circ} \mathrm{C}$, i.e., below the threshold temperature above which intense self-heating begins (Sokol 2005). Thus, only mild oxidation of coal waste organic matter occurred there (Table S2). Pronounced self-heating in the US sites involved much higher temperatures and, as a result, gas production was much intense (Table S3). There are also distinctive differences between both basins in average temperatures measured at dump surfaces and subsurface in active and inactive sites. At the active US sites, the average temperature measured at the surface was $62{ }^{\circ} \mathrm{C}$ and subsurface $137^{\circ} \mathrm{C}$, whereas those measured in the active LS sites were 38 and $66{ }^{\circ} \mathrm{C}$, respectively. At thermally inactive US sites, these temperatures were 2 and $7{ }^{\circ} \mathrm{C}$ and, for the LS, 21 and $29{ }^{\circ} \mathrm{C}$, respectively.

It follows that gas composition in the thermally active LS sites is characteristic of waning self-heating, with OD values approaching 1.0 due to the low consumption of oxygen in the process. Methane is absent, or contents are very low. This is reflected by values of $\mathrm{CH}_{4} / \mathrm{CO}_{2}$ which, at the $\mathrm{LS}$ sites, are similar to those of the US inactive sites. S/UnS follows a similar pattern. Thus, gas composition seems to mainly reflect self-heating stage and temperature level, particularly whether the threshold temperature $\left(60-80{ }^{\circ} \mathrm{C}\right.$ ) is exceeded or not (Sokol 2005; Pone et al. 2007).

However, correlations between $\mathrm{CO}_{2}$ and $\mathrm{CH}_{4}$ contents (Fig. 3) in the individual basins show a small difference, most probably caused by differences in the initial characteristics of the coal waste organic matter. The LS coals are of higher rank than the US coals (Zdanowski and Żakowa 1995). The organic matter of the adjacent waste rocks is likewise. This makes the LS coal waste organic matter more inert as labile aliphatic groups were expelled earlier during its natural maturation within the deposit and, thus, less prone to produce aliphatic compounds when heated. It also explains the slight shift in the proportions of $\mathrm{CO}_{2}$ and $\mathrm{CH}_{4}$ that reflects lower $\mathrm{CH}_{4}$ production and, thus, its rapid oxygenation to $\mathrm{CO}_{2}$ in the $\mathrm{LS}$ dumps. Moreover, this difference in organic maturity may explain why average concentrations of several dominant hydrocarbons (Table S3) are much higher in the active US sites, e.g., $\mathrm{CH}_{4}(\times 6), \mathrm{C}_{2}-\mathrm{C}_{4}$ saturates $(\times 2-7)$, propylene and acetylene $(\times 5)$ and $\mathrm{H}_{2}(\times 8)$. The lower resistance and rank of the US organic matter are also reflected in more pronounced temperature effects on gas compositions in active and inactive sites, e.g., much higher contents of $\mathrm{CH}_{4}$ and $\mathrm{C}_{2} \mathrm{H}_{6}$ 


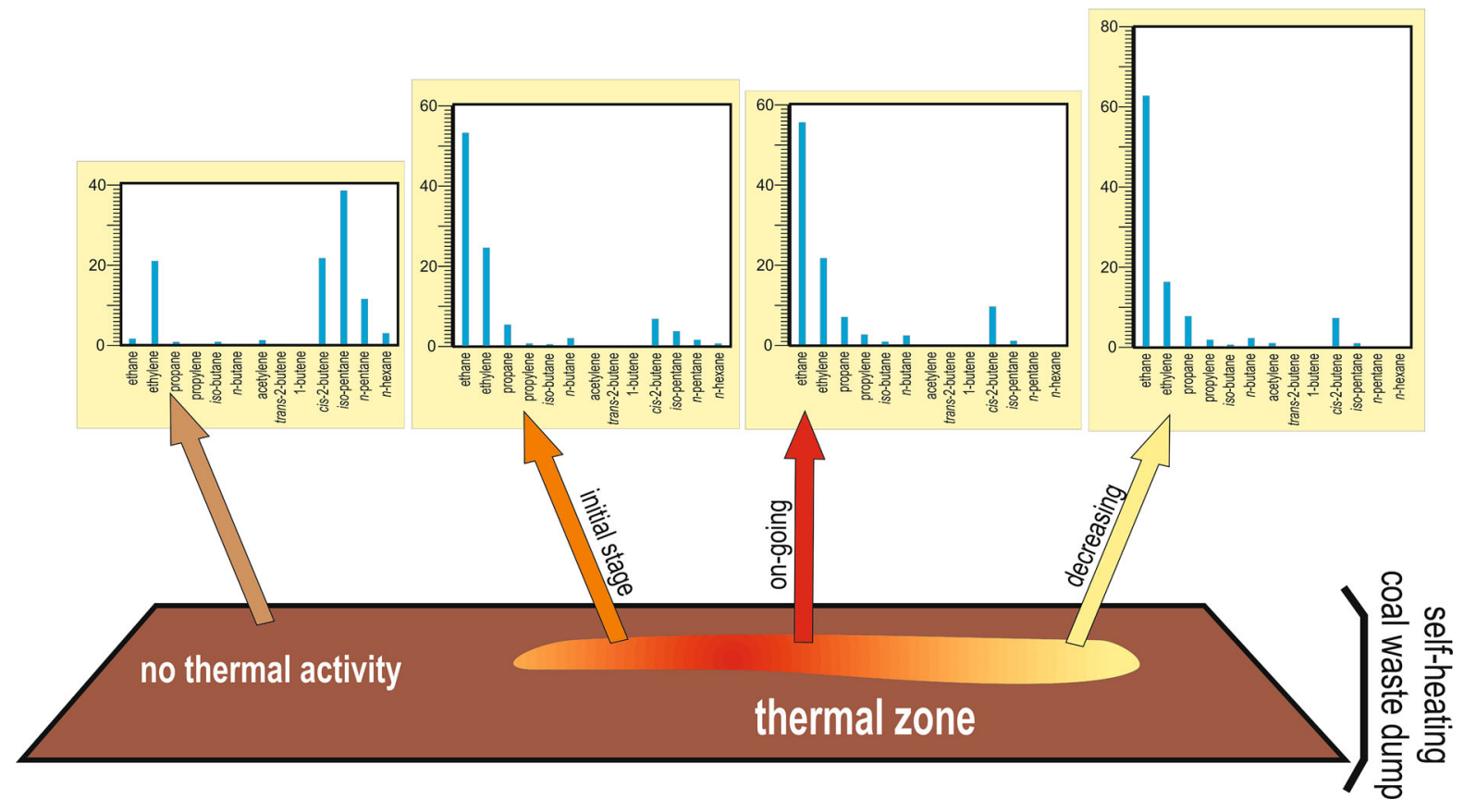

Fig. 5 Representative averaged gas compositions in thermally inactive sites and the initial, ongoing, and waning self-heating stages in the Wełnowiec dump

hydrocarbons (ca $\times 1400$ and $\times 330$, respectively) in US than in LS sites (ca $\times 20$ and $\times 220$, respectively).

Gas composition and thermal activity stage

Whereas $\mathrm{CH}_{4}$ predominates at all thermally active sites, the compositions of heavier hydrocarbons, i.e., $\mathrm{C}_{2}-\mathrm{C}_{7}$, correlate better with self-heating stages (Figs. 5 and 6). At inactive sites, apart from atmospheric gases and elevated $\mathrm{CO}_{2}, \mathrm{C}_{4}-\mathrm{C}_{6}$ hydrocarbons and ethylene, possibly of biological origin, are dominant. Initial- and waning-stage gases have compositions similar to each other, with ethane being the predominant hydrocarbon. The ongoing, well-developed stage of self-heating with site temperatures $>70{ }^{\circ} \mathrm{C}$ is characterized by slightly higher emissions of $\mathrm{C}_{3}-\mathrm{C}_{6}$ hydrocarbons compared to the initial and waning stages, commonly heavier unsaturated hydrocarbons and $\mathrm{H}_{2}$. However, the likely impossibility of reliably differentiating heating stages on gas compositions alone underscores the value of thermal mapping.
Health and environmental impact

Exceptionally high $\mathrm{CO}_{2}$ levels together with other gases emitted have adverse effects on health, particularly with whole-life exposure. It is difficult to assess how large the US and LS population is exposed to coal waste dump gases since the range of contaminant transport is unknown and most possibly affected by several factors, e.g., fire intensity, prevailing winds, and the dump architecture. Research on these problems is in its infancy. The total population of Upper Silesia is ca 4.599 million and that of Lower Silesia ca 2.910 million, with average densities of 373 and 146 person $/ \mathrm{km}^{2}$, respectively (stat.gov.pl 2014). Densities are particularly high in the areas where ca 200 US and 130 LS coal waste dumps are located, i.e., 2000-3000 person $/ \mathrm{km}^{2}$; communities clustered around the mines and associated smelters. For example, the Wełnowiec dump lies within $2.5 \mathrm{~km}$ of three Katowice districts, Koszutka, Bogucice, and Dạb, with 10000, 14000, and 7000 inhabitants, respectively. The Osiedle Tysiąclecia area slightly further away houses ca 21000 inhabitants. The worst impacts probably affect settlements such as Skała, Bunczowiec, and Bułowiec (the Rydułtowy districts with ca 8000 inhabitants) located 
Fig. 6 Comparison of gas distributions in thermally active sites and in sites with no thermal activity (rel.\% of total gas composition) in the Upper and Lower Silesian basins

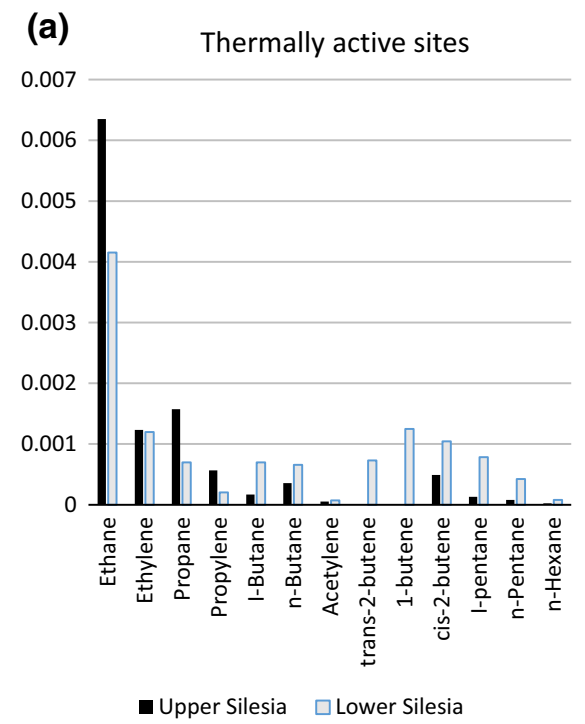

(c) Thermally active sites - unsaturated
and iso-hydrocarbons

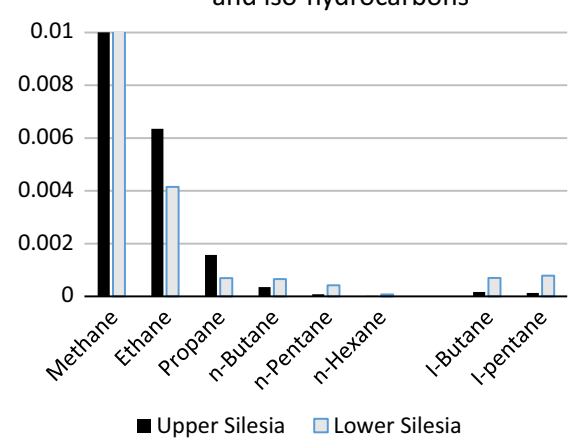

(b) No thermal activity

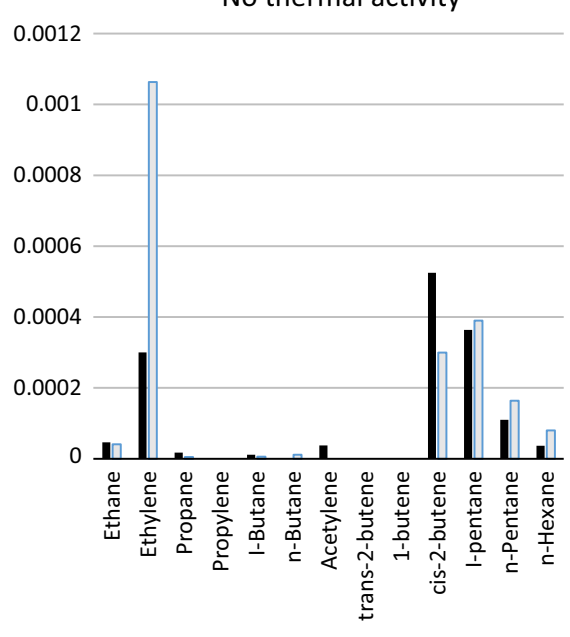

- Upper Silesia $\square$ Lower Silesia

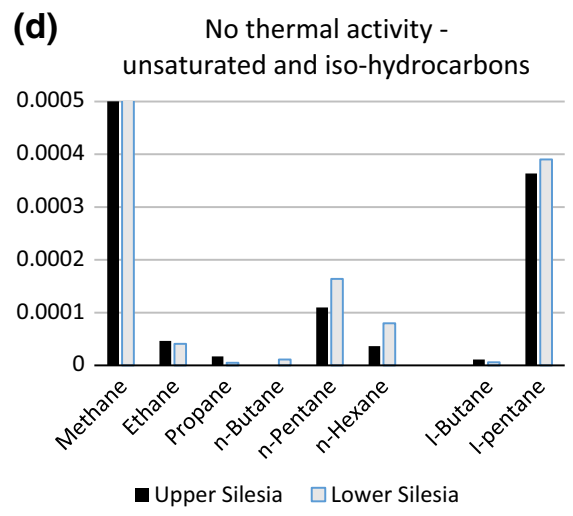

$300 \mathrm{~m}$ from the Szarlota dump, $500 \mathrm{~m}$ from the AnnaPszów dump, and ca $2 \mathrm{~km}$ from the Marcel and Rymer Cones dumps, or the Niedobczyce residential area (ca 12000 inhabitants) located 100-200 m from the Rymer Cones. Both regions are characterized by high degrees of citizens mobility to and from homes and working places every day which makes the real impact difficult to assess. However, the fact that incidences of lung cancer and other lung and cardiovascular illnesses generally are much higher in Silesia than elsewhere in Poland may be an additional indicator of exposure to self-heating pollutants (Nowotwory. 2013).

Greenhouse gas is probably the greatest concern as dump self-heating is not typically recognized as a significant source. Regrettably, awareness of the problem is low even in the scientific community, despite the worldwide occurrence of the phenomenon, e.g., Portugal, Australia, USA, China, and South Africa (e.g., Litchke 2005; Pone et al. 2007; Carras et al. 2009; Ribeiro et al. 2010; O'Keefe et al. 2010).

\section{Conclusions}

Gas emissions from coal waste dumps in two coal mining basins in Poland are characterized by highly variable compositions with $\mathrm{CO}_{2}$ and $\mathrm{CH}_{4}$, major greenhouse gases predominating in all thermally active sites. Both $\mathrm{CO}_{2}$ and $\mathrm{CH}_{4}$ can greatly exceed values considered safe for health. The thermally active dumps should be regarded as their significant source. A strong substrate-product correlation between $\mathrm{CO}_{2}$ and relative percentage contents of $\mathrm{CH}_{4}$ points to $\mathrm{CH}_{4}$ 
oxidation to $\mathrm{CO}_{2}$ immediately after $\mathrm{CH}_{4}$ release during self-heating.

Gas emissions at inactive sites comprise $\mathrm{CH}_{4}$ and smaller amounts of $\mathrm{C}_{3}-\mathrm{C}_{6}$ hydrocarbons, mostly $n$ alkanes. Concentrations of $\mathrm{CH}_{4}$ at thermally inactive sites where fire had been extinguished or which were never burnt, exceed by several times atmospheric values. At these sites, $\mathrm{CH}_{4}$ is of a possible bacterial origin (as is ethylene) or reflects long-term leakage from rock pores. Even thermally inactive coal waste dumps should be deemed a long-term environmental hazard.

The main light hydrocarbons produced during selfheating are saturates. Their dominance over unsaturated hydrocarbons increases with temperature. Acetylene is rare and other alkynes were not found, possibly due to their higher chemical reactivity.

Oxygen decrease in the gases is mostly temperature-dependent with a threshold temperature of ca $70{ }^{\circ} \mathrm{C}$. Whenever this level is reached, a significant decrease in oxygen content is registered. A strong substrate-product correlation between $\mathrm{CO}_{2}$ and $\mathrm{O}_{2}$ indicates that organic matter oxidation, not the formation of other oxides (including inorganic oxides), consumes most of the oxygen budget.

The distribution of heavier hydrocarbons in the dumps is influenced by the stage of self-heating attained. Initial and waning stages show similar gas compositions, whereas sites with ongoing self-heating show greater emission of heavier hydrocarbons, possibly related to higher temperatures. On a regional scale, the minor differences between emissions in the two Silesian coal basins are also mostly related to the self-heating stage pertaining or to differences in the thermal maturity of coal waste organic matter in both basins. The higher rank of LS organic matter makes it less prone to expelling hydrocarbons when heated. Critically, in Lower Silesia, self-heating is on the wane and most dumps already overburnt.

Since self-heating of coal waste dumps exposes large population in Upper and Lower Silesia, precautionary measures against any health dangers should be undertaken, e.g., monitoring of internal temperatures and initial-stage gases. The low threshold temperature $\left(\right.$ ca $70{ }^{\circ} \mathrm{C}$ ) means that quick and relatively inexpensive cooling of the damp is possible before the beginning of intense self-heating. Otherwise, temperatures will increase rapidly up to ignition temperature over a few weeks. Unfortunately, it is not easily possible to dismantle coal waste dumps. Due to poor mechanical quality of Silesian coal wastes, their reuse is limited to overburnt material. To limit population exposure to harmful emissions, limiting access to dumps may be advisable, particularly those with ongoing heating.

Acknowledgements Polish National Scientific Centre (NCN) Grants Nos. 2011/03/B/ST10/06331 and 2013/11/B/ST10/ 04960 partially supported the research. Dr. Pádhraig Kennan (University College, Dublin, Ireland) helped with language corrections.

Open Access This article is distributed under the terms of the Creative Commons Attribution 4.0 International License (http:// creativecommons.org/licenses/by/4.0/), which permits unrestricted use, distribution, and reproduction in any medium, provided you give appropriate credit to the original author(s) and the source, provide a link to the Creative Commons license, and indicate if changes were made.

\section{References}

Association Advancing Occupational and Environmental Health (ACGIH), (1999). In Threshold limit values for chemical substances and physical agents and biological exposure indices, Cincinnati, $\mathrm{OH}$.

Barosz, S. (2003). Technical, economical and environmental conditions of management of coal-waste dumps using the mines from the Rybnik Coal District as examples. Cracow: Academy of Mining and Metallurgy.

Borzęcki, R., \& Marek, A. (2013). Geotourist attractions of the slag heap of the former coal-mine "Nowa Ruda". In Mining History-the part of European cultural heritage 5. Wyd. Ofic. Wyd. PWroc. Wrocław, (pp. 15-25) (in Polish with English abstract).

Brake, D. J., \& Bate, G. P. (1999). Criteria for the design of emergency refuge stations for an underground metal mine. Journal of the AusIMM, 304, 1-12.

Broussard, L. (1999). Inhalants. In B. Levine (Ed.), Principles of forensic toxicology (pp. 345-353). Washington: American Association for Clinical Chemistry.

Carras, J. N., Day, S. J., Saghafi, A., \& Williams, D. J. (2009). Greenhouse gases emissions from low-temperature oxidation and spontaneous combustion at open-cut coal mines in Australia. International Journal of Coal Geology, 78, 161-168.

Ciesielczuk, J., Czylok, A., Fabiańska, M. J., \& Misz-Kennan, M. (2015). Plant occurrence on burning coal-waste-a case study from the Katowice-Wełnowiec dump, Poland. Environmental and Socio-economic Studies, 3(2), 1-10.

Ciesielczuk, J., Janeczek, J., \& Cebulak, S. (2013). The cause and progress of the endogenous coal fire in the remediated landfill in the city of Katowice. Przeglad Geologiczny, 61, 764-779.

Czechowski, F., Marzec, A., \& Czajkowska, S. (2007). Tworzenie się wodoru na drodze niskotemperaturowego 
utleniania węgla kopalnego tlenem z powietrza (Hydrogen formation upon low-temperature oxidation of bituminous coal with air oxygen, in Polish). Gospodarka Surowcami Mineralnymi, 23, 61-74.

Davidi, S., Grossman, S. L., \& Cohen, H. (1995). Organic volatile emissions accompanying the low-temperature atmospheric storage of bituminous coals. Fuel, 74, 1357-1362.

Dlugokencky, E. (2016). Trends in atmospheric methane, Global greenhouse gas reference network, NOAA Earth System Research Laboratory, (www.esrl.noaa.gov/gmd/ccgg/ trends_ch4/). Accessed 3 Sept 2017.

EPA (Environmental Protection Agency), (2005). 25-05-2005/ US-EPA/Methane/EP A-Home/Global Warming Home: accessed 17/12/2005: http:www.epa.gov/methane. Accessed 3 Sept 2017.

Fabiańska, M. J., Ciesielczuk, J., Kruszewski, Ł., Misz-Kennan, M., Blake, D. R., Stracher, G., et al. (2013). Gaseous compounds and efflorescences generated in self-heating coal-waste dumps-a case study from the Upper- and Lower Silesian Coal Basins (Poland). International Journal of Coal Geology, 116-117, 247-261.

Finkelman, R. B. (2004). Potential health impact of burning coal beds and waste banks. International Journal of Coal Geology, 59, 19-24.

Frużyński, A. (2012). Hard coal mines in Poland (pp. 1-268). Łódź: Księży Młyn Publishing House.

Grossman, S. L., Davidi, S., \& Cohen, H. (1993). Molecular hydrogen evolution as a consequence of atmospheric oxidation of coal: Batch reactor simulation. Fuel, 72, 193-197.

Grossman, S. L., Davidi, S., \& Cohen, H. (1994). Emission of toxic and fire hazardous gases from open air coal stockpiles. Fuel, 73, 1184-1188.

Gumińska, J., \& Różański, Z. (2005). Analiza aktywności termicznej śląskich składowisk odpadów powęglowych (Analysis of thermal activity in Silesian coal-waste landfills, in Polish). Karbo, 1, 53-57.

Hower, J. C., Henke, K., O'Keefe, J. M. K., Engle, M. A., Blake, D. R., \& Stracher, G. B. (2009). The Tiptop coal-mine fire, Kentucky: Preliminary investigation of the measurement of mercury and other hazardous gases from coal-fire gas vents. International Journal of Coal Geology, 80, 63-67.

Johnson, P. R., \& Ecker, J. R. (1998). The ethylene gas signal transduction pathway: A molecular perspective. Annual Review of Genetics, 32, 227-254.

Kaymakçi, E., \& Didari, V. (2002). Relations between coal properties and spontaneous combustion parameters. Turkish Journal of Engineering and Environmental Sciences, 26, 59-64.

Keqdzior, S. (2009). Accumulation of coal-bed methane in the south-west part of the Upper Silesian Coal Basin (southern Poland). International Journal of Coal Geology, 80, 20-34.

Killops, S. D., \& Killops, V. J. (2005). An introduction to organic geochemistry (pp. 1-393). Oxford: Blackwell.

Kim, A. G. (2007). Greenhouse gases generated in underground coal-mine fires. In G. B. Stracher (Ed.), Geology of coal fires: Case studies from around the world (pp. 1-13). USA: Geological Society of America.
Korban, Z. (2011). Problem of mining waste and their impact on environment in the case of burrow no. $5 \mathrm{~A} / \mathrm{W}-1$ of " $\mathrm{x}$ " mine. Górnictwo i Ekologia, 6, 109-120.

Kotarba, M. (2001). Composition and origin of coalbed gases in the Upper Silesian and Lublin basins, Poland. Organic Geochemistry, 32, 163-180.

Krishnaswamy, S., Agarwal, P. K., \& Gunn, R. D. (1996a). Low-temperature oxidation of coal. 3. Modelling spontaneous combustion in coal stockpiles. Fuel, 75, 353-362.

Krishnaswamy, S., Bhat, S., Gunn, R. D., \& Agarwal, P. K. (1996b). Low-temperature oxidation of coal. 1. Singleparticle reaction-diffusion model. Fuel, 75, 333-343.

Litschke, T. (2005) Innovative technologies for exploration, extinction and monitoring of coal fires in North China: detailed mapping of coal fire sites in combination with in situ flux measurements of combustion-gases to estimate gas flow balance and fire development (Wuda Coal Field, Inner Mongolia Autonomous Region). Unpublished $\mathrm{PhD}$ thesis, Dortmund, Universität Duisburg-Essen. http:// www.coalfire.caf.dlr.de/media/download/results/ Diplomarbeit-Litschke.pdf. Accessed on 29 March 2011.

Liu, Ch., Li, S., Qiao, Q., Wang, J., \& Pan, Z. (1998). Management of spontaneous combustion in coal mine waste tips in China. Water, Air, and Soil pollution, 103, 441-444.

Misz-Kennan, M., Ciesielczuk, J., Tabor, A. (2013) coal-waste dump fires of Poland. (Chapter 15) In Stracher, G. B., Prakash, A., Sokol, E. V. (Eds.), 2013. Coal and peat fires: A global perspective, Volume 2: Photographs and Multimedia Tours, Amsterdam: Elsevier, (pp. 233-311) (ISBN: 0978-0-444-59412-9).

Nádudvari, Á. (2014). Thermal mapping of self-heating zones on coal-waste dumps in Upper Silesia (Poland) - a case study. International Journal of Coal Geology, 128-129, 47-54.

Nádudvari, Á., \& Fabiańska, M. J. (2016). Use of geochemical analysis and vitrinite reflectance to assess different selfheating processes in coal-waste dumps (Upper Silesia, Poland). Fuel, 181, 102-119.

Nagahama, K., Ogawa, T., Fuji, T., \& Fukuda, H. (1992). Classification of ethylene-producing bacteria in terms of biosynthetic pathways to ethylene. Journal of Fermentation and Bioengineering, 73, 1-5.

Nowotwory złośliwe w województwie śląskim (Malicious cancers in Silesia District), (2013). (Ed.) Śląski Urząd Wojewódzki w Katowicach Wydział Nadzoru nad Systemem Opieki Zdrowotnej Oddział Analiz i Statystyki Medycznej, (pp. 81).

O’Keefe, J. M. K., Hanke, K. H., Hower, J. C., Engle, M. A., Stracher, G. B., Stucker, J. D., et al. (2010). $\mathrm{CO}_{2}$, CO, and $\mathrm{Hg}$ emissions from the Truman Shepherd and Ruth Mullins coal fires, eastern Kentucky, USA. Science of the Total Environment, 408, 1628-1633.

Parafiniuk, J., \& Kruszewski, Ł. (2010). Minerals of the ammonioalunite-ammoniojarosite series formed on a burning coal dump at Czerwionka, Upper Silesian Coal Basin. Poland. Mineral Magazine, 74(4), 731-745.

Pauluhn, J. (2016). Risk assessment in combustion toxicology: Should carbon dioxide be recognized as a modifier of toxicity or separate toxicological entity? Toxicology Letters, 262, 142-152. 
Peischl, J., Ryerson, T. B., Aikin, K. C., de Gouw, J. A., Gilman, J. B., Holloway, J. S., et al. (2015). Quantifying atmospheric methane emissions from the Haynesville, Fayetteville, and northeastern Marcellus shale gas production regions. Journal of geophysical Research: Atmospheres, 120, 2119-2139.

Peters, V., \& Conrad, R. (1995). Methanogenic and other strictly anaerobic bacteria in desert soil and other oxic soils. Applied and Environmental Microbiology, 61(4), 1673-1676.

Pone, J. D. N., Hein, K. A. A., Stracher, G. B., Annegarn, H. J., Finkelman, R. B., Blake, D. R., et al. (2007). The spontaneous combustion of coal and its by-products in the Witbank and Sasolburg coalfields of South Africa. International Journal of Coal Geology, 72, 124-140.

Prakash, A., Schaefer, K., Witte, W. K., Collins, K., Gens, R., \& Goyette, M. P. (2011). A remote sensing and GIS based investigation of a boreal forest coal fire. International Journal of Coal Geology, 86, 79-86.

Querol, X., Izquierdo, M., Monfort, E., Alvarez, E., Font, O., Moreno, T., et al. (2008). Environment characterization of burnt coal gangue banks at Yangquan, Shanxi Province, China. International Journal of Coal Geology, 75, 93-104.

Querol, X., Zhuang, X., Font, O., Izquierdo, M., Alastuey, A., Castro, I., et al. (2011). Influence of soil cover on reducing the environmental impact of spontaneous coal combustion in coal-waste gobs: A review and new experimental data. International Journal of Coal Geology, 85, 2-22.

Ribeiro, J., Ferreira, da Silva, E., \& Flores, D. (2010). Burning of coal-waste piles from Douro Coalfield (Portugal): Petrological, geochemical and mineralogical characterization. International Journal of Coal Geology, 81, 359-372.

Saavedra, J., Merino, L., \& Kafarov, V. (2013). Determination of the gas composition effect in carbon dioxide emission at refinery furnaces. Chemical Engineering Transactions, 35, 1357-1362.

Schneising, O., Burrows, J. P., Dickerson, R. R., Buchwitz, M., Reuter, M., \& Bovensmann, H. (2014). Remote sensing of fugitive methane emissions from oil and gas production in North American tight geologic formations. Earth's Future, 2, 548-558.

Singh, A. K., Singh, R. V. K., Singh, M., Chandra, H., \& Shukla, N. K. (2007). Mine fire gas indices and their application to Indian underground coal mine fires. International Journal of Coal Geology, 69, 192-204.

Skręt, U., Fabiańska, M. J., \& Misz-Kennan, M. (2010). Simulated water-washing of organic compounds from selfheated coal-wastes of the Rymer Cones Dump (Upper Silesia Coal Region, Poland). Organic Geochemistry, 41, 1009-1012.
Sokol, E. V. (2005). High-temperature processes of organic fuel decomposition as a thermal source for pyrometamorphic transformations. In G. G. Lepezin (Ed.), Combustion metamorphism (pp. 22-31). Novosybirsk: Publishing House of the Siberian Branch of Russian Academy of Sciences. (in Russian).

Speight, J.G. (2014). The chemistry and technology of petroleum, 5th Edition. Chemical Industries. CRC Group, Taylor \& Francis Group, (pp. 1-928).

Stracher, G. B., \& Taylor, T. P. (2004). Coal fires burning out of control around the world: Thermodynamic recipe for environmental catastrophe. International Journal of Coal Geology, 59, 7-17.

Tabor, A. (2002). Monitoring of coal-waste dumps, re-cultivated dumps and other collection sites of Carboniferous waste rocks in the light of many years experience. In VII Conference "Long term proecological undertakings in the Rybnik Coal Area”, Rybnik, (pp. 131-141) (in Polish).

Tetzlaff, A. (2004). Coal Fire quantification using ASTER, ETM and BIRD satellite instrument data. $\mathrm{PhD}$ thesis Ludwig Maximilians University, Munich, Germany, (pp. 2-148), http://edoc.ub.uni-muenchen.de/4398/1/tetzlaff_ anke.pdf. Accessed 4 July 2018.

Tung, H. C., Bramall, N. E., \& Price, P. B. (2005). Microbial origin of excess methane in glacial ice and implications for life on Mars. Proceedings of the National Academy of Sciences, 102(51), 18292-18296.

www.ogimet.com.

www.landsat.usgs.gov/what-are-band-designations-landsatsatellites.

www.stat.gov.pl, (2014).

Xie, J., Xue, Sh, Cheng, W., \& Wang, G. (2011). Early detection of spontaneous combustion of coal in underground coal mines with development of an ethylene enriching system. International Journal of Coal Geology, 85, 123-127.

Yan, R., Zhu, H., Zheng, Ch., \& Xu, M. (2003). Emissions of organic hazardous air pollutants during Chinese coal combustion. Energy, 27, 485-503.

Younger, P.L. (2004). Environmental impacts of coal mining and associated wastes: a geochemical perspective. In: R. Gieré, P. Stille, (Eds.) Energy, waste and the environment: a geochemical perspective, Geol. Soc. Spec. Publ. 236, (pp. 169-209).

Zdanowski, A., \& Żakowa H. (1995). The Carboniferous system in Poland. Works of Polish Geological Institute, (p. 215).

Zhang, J., \& Kuenzer, C. (2007). Thermal surface characteristics of coal fires 1: Results of in situ measurements. Journal of Applied Geophysics, 63, 117-134. 